\title{
Locus Coeruleus Ablation Exacerbates Cognitive Deficits, Neuropathology, and Lethality in P301S Tau Transgenic Mice
}

\author{
Termpanit Chalermpalanupap, ${ }^{1}$ Jason P. Schroeder, ${ }^{1}$ Jacki M. Rorabaugh, ${ }^{1}$ L. Cameron Liles, ${ }^{1}$ James J. Lah, ${ }^{2}$ \\ (1)Allan I. Levey, ${ }^{2}$ and David Weinshenker ${ }^{1}$ \\ Departments of ${ }^{1}$ Human Genetics and ${ }^{2}$ Neurology, Emory University, Atlanta, Georgia 30322
}

\begin{abstract}
The brainstem locus coeruleus (LC) supplies norepinephrine to the forebrain and degenerates in Alzheimer's disease (AD). Loss of LC neurons is correlated with increased severity of other AD hallmarks, including $\beta$-amyloid $(\mathrm{A} \beta)$ plaques, tau neurofibrillary tangles, and cognitive deficits, suggesting that it contributes to the disease progression. Lesions of the LC in amyloid-based transgenic mouse models of $\mathrm{AD}$ exacerbate $\mathrm{A} \beta$ pathology, neuroinflammation, and cognitive deficits, but it is unknown how the loss of LC neurons affects tau-mediated pathology or behavioral abnormalities. Here we investigate the impact of LC degeneration in a mouse model of tauopathy by lesioning the LC of male and female P301S tau transgenic mice with the neurotoxin $\mathrm{N}$-(2-chloroethyl)- $\mathrm{N}$-ethyl-bromobenzylamine (DSP-4) starting at 2 months of age. By 6 months, deficits in hippocampal-dependent spatial (Morris water maze) and associative (contextual fear conditioning) memory were observed in lesioned P301S mice while performance remained intact in all other genotype and treatment groups, indicating that tau and LC degeneration act synergistically to impair cognition. By 10 months, the hippocampal neuroinflammation and neurodegeneration typically observed in unlesioned P301S mice were exacerbated by DSP-4, and mortality was also accelerated. These DSP-4-induced changes were accompanied by only a mild aggravation of tau pathology, suggesting that increased tau burden cannot fully account for the effects of LC degeneration. Combined, these experiments demonstrate that loss of LC noradrenergic neurons exacerbates multiple phenotypes caused by pathogenic tau, and provides complementary data to highlight the dual role LC degeneration has on both tau and $\mathrm{A} \beta$ pathologies in $\mathrm{AD}$.
\end{abstract}

Key words: DSP-4; hippocampus; locus coeruleus; neuroinflammation; norepinephrine; tau

\section{Significance Statement}

Elucidating the mechanisms underlying $\mathrm{AD}$ is crucial to developing effective diagnostics and therapeutics. The degeneration of the LC and loss of noradrenergic transmission have been recognized as ubiquitous events in AD pathology, and previous studies demonstrated that LC lesions exacerbate pathology and cognitive deficits in amyloid-based mouse models. Here, we reveal a complementary role of LC degeneration on tau-mediated aspects of the disease by using selective lesions of the LC and the noradrenergic system to demonstrate an exacerbation of cognitive deficits, neuroinflammation, neurodegeneration in a transgenic mouse model of tauopathy. Our data support an integral role for the LC in modulating the severity of both canonical $\mathrm{AD}$-associated pathologies, as well as the detrimental consequences of $\mathrm{LC}$ degeneration during disease progression.

\section{Introduction}

Alzheimer's disease (AD) is a debilitating neurodegenerative disorder and one of the leading causes of dementia and death in the

\footnotetext{
Received May 27, 2017; revised 0ct. 3, 2017; accepted Nov. 3, 2017.

Author contributions: T.C., J.P.S., J.J.L., A.I.L., and D.W. designed research; T.C., J.P.S., J.M.R., and L.C.L. performed research; T.C. and D.W. analyzed data; T.C. and D.W. wrote the paper.

This work was supported by the National Institutes of Health Grant AG025688 to A.I.L. and D.W. and Grant AG047667 to D.W., and the Alzheimer's Association Grant IIRG-13-278692 to D.W. We thank Marla Gearing for help with histology; and Ellen Hess and Rong Fu for assistance with HPLC.

The authors declare no competing financial interests.

Correspondence should be addressed to Dr. David Weinshenker, Department of Human Genetics, Emory University School of Medicine, 615 Michael Street, Whitehead 301, Atlanta, GA 30322. E-mail: dweinshenker@genetics.emory.edu.
}

United States, yet there is still no clear mechanism that explains its initiation or progression. Because symptoms do not emerge for years or even decades after pathology starts accumulating, it is crucial to ascertain where and when the disease begins to effectively diagnose and treat it. Degeneration of the noradrenergic brainstem locus coeruleus (LC) is an early and ubiquitous feature of $\mathrm{AD}$ that correlates well with many of its other elements, such as $\beta$-amyloid (A $\beta$ ) plaques, tau neurofibrillary tangles, and cognitive impairment (Iversen et al., 1983; Mann, 1983; Bondareff et al., 1987; Chan-Palay and Asan, 1989; Haglund et al., 2006; Grudzien et al.,

D0I:10.1523/JNEUROSCI.1483-17.2017

Copyright $\odot 2018$ the authors $\quad 0270-6474 / 18 / 380074-19 \$ 15.00 / 0$ 
2007). Norepinephrine (NE) is important for many AD-relevant behaviors and cognitive functions (e.g., arousal, attention, affective behaviors, learning, and memory) in addition to having anti-inflammatory and neuroprotective properties (Szabadi, 2013; Feinstein et al., 2016; Mather and Harley, 2016). Thus, as the sole source of NE to critical $\mathrm{AD}$-associated brain regions, such as the hippocampus and frontal cortex, damage to the LC likely contributes to disease progression and severity (Mann, 1983; Zweig et al., 1989; Jalbert et al., 2008; Weinshenker, 2008; Gannon et al., 2015).

LC cell loss in AD patients is reported to range from $40 \%$ to 80\% (German et al., 1992; Lyness et al., 2003). By contrast, only a handful of transgenic animal models of $\mathrm{AD}$ report endogenous LC degeneration or dysfunction; and even then, the damage is modest (Liu et al., 2008; Guérin et al., 2009; Liu et al., 2013). Although this limits the validity of the models, it also provides a unique opportunity to induce LC damage/dysfunction and investigate its impact within the context of $\mathrm{AD}$-like neuropathology and cognitive deficits. These approaches have been used extensively to understand the role of the LC in $A \beta$ models of AD. Several groups have lesioned the LC in various amyloid precursor protein (APP) transgenic mice (e.g., APP23, F717F APP, APP/ PS1) using the selective LC neurotoxin, $N$-(2-chloroethyl)- $N$ ethyl-bromo-benzylamine (DSP-4), and reported exacerbation of $\mathrm{A} \beta$ plaque deposition, neuroinflammation, and cognitive and behavioral deficits (Heneka et al., 2006; Kalinin et al., 2007; Rey et al., 2012). APP/PS1 mice crossed with either NE-deficient dopamine $\beta$-hydroxylase knock-out $\left(\mathrm{Dbh}^{-/-}\right)$mice or Ear2 knockout mice that have impaired specification of LC neurons show a profound synergistic exacerbation of the cognitive impairments observed in the single mutants (Hammerschmidt et al., 2013; Kummer et al., 2014). In both instances, these impairments could be at least partially rescued by pharmacological restoration of NE.

Combined, these findings emphasize the importance of the $\mathrm{LC} / \mathrm{NE}$ system in gating $\mathrm{A} \beta$-associated neuropathology and cognitive deficits. However, because there is currently no information regarding the consequences of LC degeneration on tau, the overall repercussions of noradrenergic dysfunction in $\mathrm{AD}$ remain murky. Here we examined the impact of DSP-4 LC lesions on tau-mediated neuropathology and behavioral abnormalities in P301S tau transgenic mice. Although neither this mutation nor any known tau mutation causes $\mathrm{AD}$ in humans, we selected this model of tauopathy for three reasons. First, P301S tau is prone to hyperphosphorylation and induces the formation of aberrant tau species reminiscent of those found in AD (Bugiani et al., 1999; Yasuda et al., 2000; Lossos et al., 2003; Yoshiyama et al., 2007). Second, P301S tau confers neuroinflammation, neurodegeneration, and cognitive impairment in both mice and humans (Bugiani et al., 1999; Bugiani, 2000; Yasuda et al., 2000; Lossos et al., 2003; Takeuchi et al., 2011). Finally, a similar mutation (P301L) has been used in combination with AD-causing APP and presenilin-1 (PS1) mutations to generate one of the more comprehensive $\mathrm{AD}$ mouse models to date, encompassing both $\mathrm{A} \beta$ and tau pathologies (Oddo et al., 2003). Understanding how LC degeneration and the subsequent loss of NE impacts tau, in addition to $\mathrm{A} \beta$, will provide a more comprehensive view of the contribution of this pathology $\mathrm{AD}$.

\section{Materials and Methods}

Animals. Male and female P301S transgenic mice (B6N.Cg-Tg(Prnp-

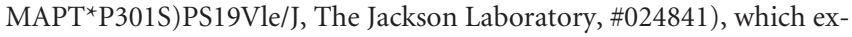
press the $4 \mathrm{~N} 1 \mathrm{R}$ isoform of human microtubule-associated protein tau with the frontotemporal dementia-causing P301S mutation under the mouse prion promoter, were used. P301S mice were purchased and maintained as hemizygotes on a C57BL/6 background. Nontransgenic wild-type (WT) littermates were used as controls. P301S mice are reported to develop extensive astrogliosis and microgliosis beginning at 3 months, followed by progressive accumulation of neurofibrillary tangles beginning at 6 months (Yoshiyama et al., 2007; Takeuchi et al., 2011). From 9 to 12 months, neuronal loss is observed in the hippocampus and entorhinal cortex (Yoshiyama et al., 2007). These mice also manifest cognitive and behavioral impairments concomitantly with the establishment of their neuropathology (Yoshiyama et al., 2007; Takeuchi et al., 2011). Mice were group housed (maximum of 5 animals per cage) during the entire experiment, except for a $24 \mathrm{~h}$ separation during circadian rhythm testing when they were singly housed. All experiments were conducted at Emory University in accordance with the National Institutes of Health Guide for the Care and Use of Laboratory Animals and approved by the Emory Institutional Animal Care and Use Committee.

DSP-4 lesions. There were four groups of animals within each age group (4, 6, and 10 months): vehicle-treated P301S, DSP-4-treated P301S, vehicle-treated WT, and DSP-4-treated WT. At $\sim 2$ months of age, mice began their treatment regimen with two initial doses of DSP-4 $(50 \mathrm{mg} / \mathrm{kg}$, i.p.) or vehicle $(0.9 \% \mathrm{NaCl})$ administered on day 1 and day 7 . Animals then received a monthly booster (vehicle or $50 \mathrm{mg} / \mathrm{kg}$ DSP-4), with the final dose ending 1 month before behavioral testing which began at 4, 6 , and 10 months of age. This dosing paradigm was based on previous studies performing similar lesions in amyloid transgenic mouse models of AD (Heneka et al., 2006; Jardanhazi-Kurutz et al., 2010). Behavioral testing spanned 4 weeks; thus, mice were 5, 7, and 11 months old at the time of death for histology (see Fig. 1A).

Circadian rhythm/locomotor activity. Mice were placed in locomotor recording chambers (transparent Plexiglas cages placed into a rack with 7 infrared photobeams spaced $5 \mathrm{~cm}$ apart; San Diego Instruments), with bedding, food, and water at 9:30 A.M., and ambulations (consecutive beam breaks) were automatically recorded for $24 \mathrm{~h}$ in $10 \mathrm{~min}$ bins.

Open field. The circular open field arena ( $1 \mathrm{~m}$ in diameter) was white with gray walls ( $35 \mathrm{~cm}$ high) and was brightly illuminated. The arena was divided into two zones: an inner circle $(60 \mathrm{~cm}$ in diameter $)$ and the surrounding outside (width $20 \mathrm{~cm}$ ). Each animal was placed in the center at the start of the trial and given 10 min to freely explore the arena. An automated tracking system (TopScan, CleverSys) recorded the distance traveled, velocity, and duration of time spent in the inside and outside zones. The arena was cleaned in between trials with Quatracide (Pharmacal Research Laboratories). The percentage of time spent in the inner circle versus the outer circle, as well as the latency to escape to the outer ring, were used as measures of anxiety-like behavior.

Morris water maze. The Morris water maze was conducted in a circular tank (52 inches in diameter) filled with water, made opaque with white paint, at $23^{\circ} \mathrm{C}$. In the northwestern quadrant of the tank, a hidden circular platform $(30 \mathrm{~cm}$ diameter) was present $1 \mathrm{~cm}$ below the water surface. The tank was brightly lit and flanked by white walls on the north and east sides, and white curtains on the west and south sides of the tank, all with external cues for spatial references. Over 5 days, mice were trained to find the platform when released into the tank from randomized start points over 4 trials each day (south, north, east, west). Each trial lasted a maximum of $60 \mathrm{~s}$. If a mouse did not successfully find the platform in time, it was manually guided to it and allowed to sit on the platform for $10 \mathrm{~s}$. An automated tracking system was used to record the latency and distance to the platform as well as speed (TopScan, CleverSys). On the sixth day, a probe trial was conducted where the platform was removed and mice were released from the south start point and allowed to swim for $60 \mathrm{~s}$. The automated tracking system recorded the duration and distance the mice spent in each quadrant of the maze, as well as the number of times they crossed over the previous location of the platform.

Fear conditioning. Fear conditioning training and contextual and cued fear testing were conducted over 3 consecutive days. The chamber $(7$ inches width $\times 7$ inches length $\times 12$ inches height, H10-11M-TC, Coulbourn Instruments) was equipped with a house light, an electric grid shock floor (H10-11M-TC, Coulbourn Instruments) that could be removed and replaced with a nonshock wire mesh floor (H10-11-M-TC, Coulbourn Instruments), a ceiling-mounted camera providing a topdown view of the chamber, and a speaker. Chambers were cleaned in 
between animals with Quatricide. The acquisition trial on day 1 lasted 7 min and began with a 3 min acclimatization period, followed by 3 toneshock pairings during which the tone was present for $20 \mathrm{~s}$ and was coterminated with a $3 \mathrm{~s}, 0.5 \mathrm{~mA}$ foot shock. Mouse behavior was recorded for $60 \mathrm{~s}$ following tone-shock presentation before the next round. Contextual fear testing on day 2 was performed in the same chamber as day 1 and lasted $8 \mathrm{~min}$ without any presentation of tone or shock. Cued fear testing on day 3 was conducted in a different chamber than days 1 and 2, with a square mesh floor instead of the previous shock grid floor. The cued fear testing trial lasted $9 \mathrm{~min}$, with the tone starting after $3 \mathrm{~min}$ and continuing until the end of the trial. Trials were programmed and run using the FreezeFrame software (Coulbourn Instruments) to automatically record freezing behavior during each trial.

Physical phenotypes and survival. Neurodegenerative-associated physical phenotypes (kyphosis and hindlimb clasping) were measured before death for histology and scored according to previously established protocol (Guyenet et al., 2010). Kyphosis is a dorsal curvature of the spine caused by loss of muscle tone in spinal muscles. To perform the kyphosis test, mice were removed from the cage, observed while walking on a flat surface, and scored per the rating scale outlined in the protocol. To perform the hindlimb test, mice were firmly grasped by the base of the tail and lifted for $10 \mathrm{~s}$. Scoring was performed per the rating scale outlined in the protocol. Mouse deaths not associated with obvious environmental hazards (e.g., cage flood) were recorded and plotted on a Kaplan-Meier survival graph.

Perfusion and brain dissection. Mice were anesthetized with a mixture of ketamine (100 mg/kg, i.p.) and xylazine (20 mg/kg, i.p.). To prevent tau hyperphosphorylation due to anesthesia-induced hypothermia (Planel et al., 2007; Bretteville et al., 2012; Carrettiero et al., 2015), mice were kept on top of a heating pad until fully anesthetized. Mice were transcardially perfused with cold $0.1 \mathrm{M}$ PBS until their livers were cleared of blood. Brains were removed and split sagitally into two hemispheres using an acrylic mouse brain mold (Ted Pella, \#15050). One hemisphere was drop-fixed overnight in 4\% PFA in PBS for immunohistochemistry. The other hemisphere was microdissected on ice, and the olfactory bulb, prefrontal cortex, hippocampus, brainstem, and remaining cortex were individually frozen and stored at $-80^{\circ} \mathrm{C}$ before biochemical processing.

Immunohistochemistry. Mouse brain hemispheres were dehydrated in ethanol, embedded into paraffin blocks, sliced with a microtome at $8 \mu \mathrm{m}$, and mounted onto slides. Slides were processed by deparaffinization in xylene and rehydration through an ethanol series. Slides to be processed with $\mathrm{DAB}$ immunohistochemistry were incubated with 3\% hydrogen peroxide in methanol for $20 \mathrm{~min}$ before rehydrating in distilled water. Antigen retrieval was performed by incubating slides in a $10 \mathrm{~mm}$ sodium citrate solution, $\mathrm{pH} 6.0$, with $0.5 \%$ Tween 20 for $10 \mathrm{~min}$ at $90^{\circ} \mathrm{C}$. Slides were allowed to cool to $50^{\circ} \mathrm{C}$ before washing in distilled water and transferring to PBS. Nonspecific binding of proteins was blocked by incubating in a solution containing 3\% BSA and $0.1 \%$ Triton X-100 in PBS for 30 $\mathrm{min}$ at room temperature before washing with PBS before antibody incubation in a humidified chamber overnight, also at room temperature. Primary antibodies included mouse anti-norepinephrine transporter (NET) (1:1000, Mab Technologies, \#NET05-2), rabbit anti-ionized calcium-binding adapter molecule 1 (Iba1) (1:1000, Wako, \#019-19741), rat anti-glial fibrillary acidic protein (GFAP) (1:1000, Invitrogen, \#130300), mouse anti-Ser202, Thr205 (AT8) (1:500, ThermoScientific, MN1020), mouse anti-Ser396,404 (PHF1) (1:500, courtesy of Peter Davies, Albert Einstein College of Medicine), and mouse anti-NeuN (1:100, Millipore, MAB377). Slides were washed multiple times with PBS and incubated with either biotinylated or fluorescently labeled secondary antibodies for $2 \mathrm{~h}$ at room temperature. Immunofluorescent slides were treated for 5 min with Hoechst dye ( $12 \mu \mathrm{g} / \mathrm{ml}$, Sigma-Aldrich, B1155) before the final PBS wash and coverslipping with Fluoromont Aqueous Mounting Medium (Sigma-Aldrich, F4680). Biotinylated slides were washed in PBS, incubated for $2 \mathrm{~h}$ with $\mathrm{ABC}$ solution (Vectastain Elite ABC HRP Kit, Vector Laboratories, PK-6100) at room temperature, washed again in PBS, and developed using SIGMAFAST DAB (Sigma-Aldrich, D4293) for $10 \mathrm{~min}$. Slides were washed in PBS again before dehydrating with an ethanol and xylene gradient and coverslipping with Permount mounting medium (Fisher Scientific, SP15-100). For DAB-stained slides, serial slides were counterstained with cresyl violet $(0.5 \%$, Sigma-Aldrich, C5042). For AT8 and PHF1 figures, slides were chosen so that the same cresyl violet images could be used as counterstains for both figures. All slides were air dried before viewing with a microscope (DM6000B, Leica). The Allen p56 Mouse Brain Atlas version 1 (2008) was used to identify brain regions of interest (ROIs). One section per mouse containing the hippocampus (at bregma $\sim-1.995 \mathrm{~mm}$ ) was analyzed per antibody (NET, Iba1, GFAP, NeuN, AT8, and PHF1). One section per mouse containing the LC (at bregma $\sim-5.555 \mathrm{~mm}$ ) was also analyzed for NET immunoreactivity (IR). IR was calculated as percentage area of total ROI region (either hippocampus or LC) within ImageJ. Images were blinded, and a threshold for IR was determined across all images for each antibody. A standard ROI was drawn for each ROI (LC, CA3, CA1, and DG) using neuronal counterstain images as a guide. The total area of the ROI as well as area of IR within the ROI were calculated using the "Measure" feature of ImageJ and used to determine the percentage area of immunoreactivity (area of IR within ROI divided by total area of ROI and multiplied by 100).

HPLC. Frozen microdissected tissue was sonicated with $10 \mathrm{~s}$ of $1 \mathrm{~s}$ pulses in $10 \times$ (volume/weight) $25 \mathrm{~mm}$ Tris buffer, $\mathrm{pH} 7.4$, and split into equal volumes for use in multiple biochemical tests. An equal volume of $0.2 \mathrm{~N}$ perchloric acid solution was added to the volume of sonicated tissue (for a final perchloric acid concentration of $0.1 \mathrm{~N}$ ), followed by gentle tapping to mix and centrifugation at $13,000 \mathrm{rpm}$ at $4^{\circ} \mathrm{C}$ for $15 \mathrm{~min}$. Supernatant was collected and filtered through a $0.45 \mu \mathrm{m}$ filter on a tabletop centrifuge at $13,000 \mathrm{rpm}$ at $4^{\circ} \mathrm{C}$ for $10 \mathrm{~min}$. Samples were run using an ESA 5600A CoulArray detection system, equipped with an ESA Model 582 pump and an ESA 542 refrigerated autosampler. Separations were performed at room temperature using an MD-150 $\times 3.2 \mathrm{~mm} \mathrm{C18}$ column. The mobile phase consisted of $1.7 \mathrm{~mm} 1$-octanesulfonic acid sodium, $75 \mathrm{~mm} \mathrm{NaH} \mathrm{PO}_{4}, 0.025 \%$ triethylamine, and $9 \%$ acetonitrile, $\mathrm{pH} 3.01 ; 20 \mu \mathrm{l}$ of sample was injected. The samples were eluted isocratically at $0.4 \mathrm{ml} / \mathrm{min}$ and detected using a 6210 electrochemical cell equipped with 5020 guard cell. Guard cell potential was set at $600 \mathrm{mV}$, whereas analytical cell potentials were $-175,100,350$, and $425 \mathrm{mV}$. The analytes were identified by the matching criteria of retention time and sensor ratio measures to known standards (Sigma-Aldrich). Compounds were quantified by comparing peak areas with those of standards on the dominant sensor.

Experimental design and statistical analysis. Experimental design was based on previous studies performing similar lesions in transgenic mouse models of AD (Heneka et al., 2006; Jardanhazi-Kurutz et al., 2010). Animal groups were sex-balanced as much as possible, and numbers were as follows (female/male): 4 months, WT + saline (6/6), WT + DSP-4 (6/6), P301S + saline (7/5), P301S + DSP-4 (7/5); 6 months, WT + saline (7/5), WT + DSP-4 (6/6), P301S + saline (5/4), P301S + DSP-4 (6/4); 10 months, WT + saline (6/6), WT + DSP-4 (6/6), P301S + saline (8/4), P301S + DSP-4 (7/5). Although the experiments were not sufficiently powered to detect significant sex differences, nothing overt was observed, and data from males and females in the same genotype/treatment group were combined. Immunohistochemistry was performed on one atlasmatched section per brain area per animal per antibody. Animals with damaged sections were excluded from the analysis for that antibody or brain region. Each animal was run through all behavioral experiments. Animals deemed unable to perform any experiment (e.g., swim during the Morris water maze) were removed from the experiment and excluded from that analysis.

The majority of data were analyzed via two-way ANOVA with varying factors depending on the test, followed by post hoc tests where appropriate for multiple comparisons. The exception was mortality data, which were analyzed using the Mantel-Cox test. Significance was set at $p<0.05$, with two-tailed variants of tests implemented. Multiplicity-adjusted $p$ value was reported for each comparison. Data are presented as mean \pm SEM. Calculations were performed and figures created using Prism version 6 for Windows (GraphPad Software). 
A

\section{$\Delta \quad$ DSP-4 treatment Sacrifice at $5 \mathrm{mo}$}

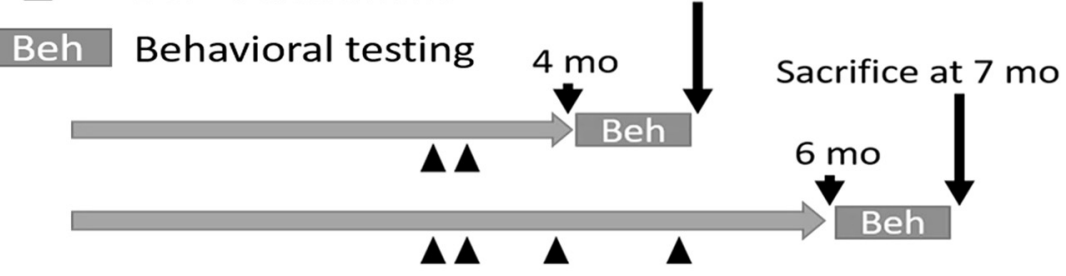

Sacrifice at $11 \mathrm{mo}$

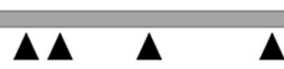

$\Delta$

$\boldsymbol{\Delta}$

$\Delta$

$\Delta$

C

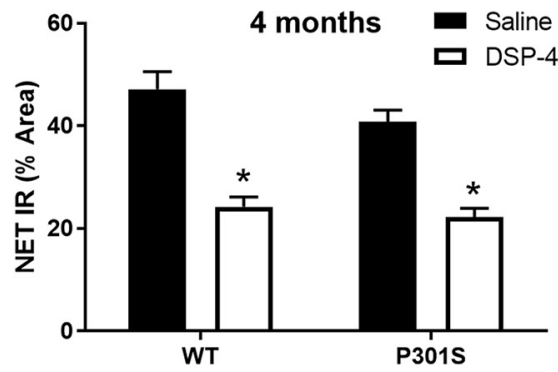

B
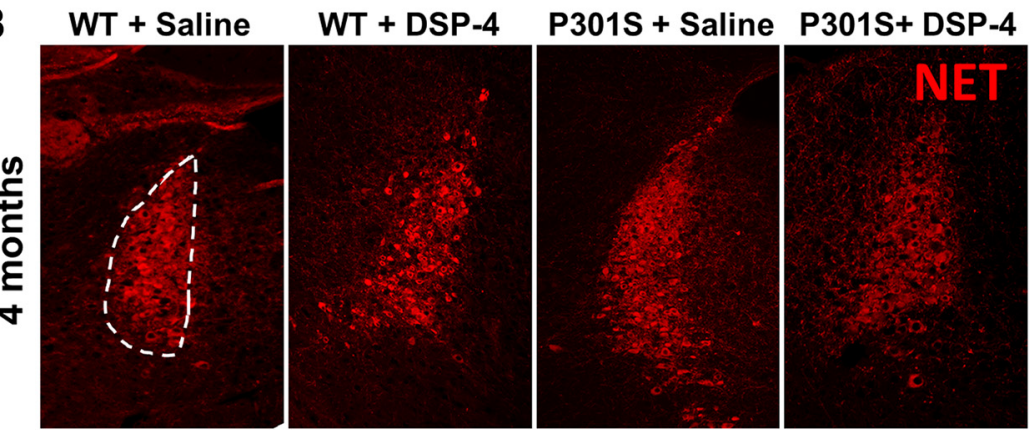

D
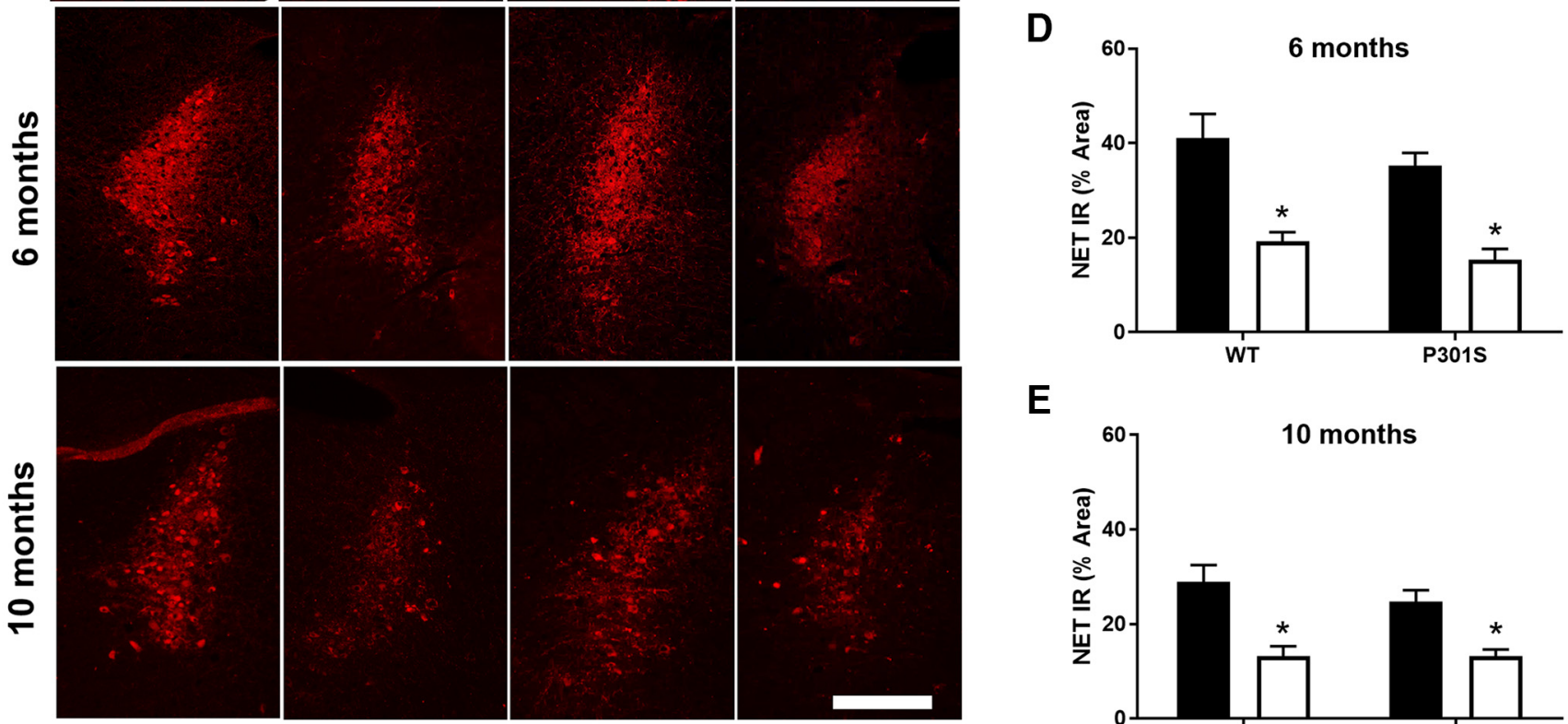

E

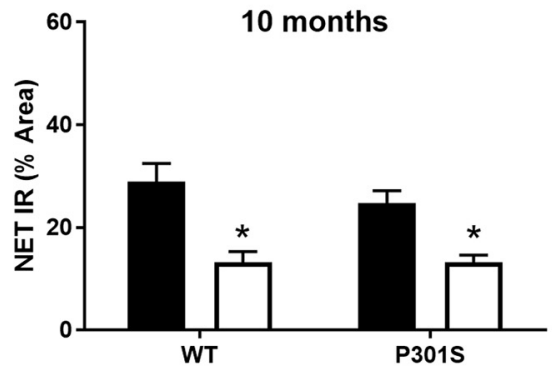

Figure 1. DSP-4 reduces NET IR in the LC of both WT and P3015 mice. WT and P3015 mice were administered multiple doses of saline or DSP-4 (50 mg/kg, i.p.) and then assessed for behavior and pathology at various time points. $\boldsymbol{A}$, Timeline of experiments. $\boldsymbol{B}$, Representative immunofluorescence images. $\boldsymbol{C}-\boldsymbol{E}$, Quantification of the NET IR in the LC as percentage of total $L C$ area. Two-way ANOVA (treatment $\times$ genotype) with Sidak's post hoc tests. Data are mean \pm SEM; $n=8-12$ per group. Scale bar, $100 \mu \mathrm{m} .{ }^{*} p<0.05$, compared with saline for that genotype.

\section{Results}

DSP-4 induces degeneration of LC cell bodies as well as loss of LC fibers and NE in the hippocampus

We visualized the effect of DSP-4 on the LC system using IR for the NET, a reliable marker of noradrenergic neurons that also shows a marked decrease in AD patients (Gulyas et al., 2010). DSP-4 (50 mg/kg, i.p.; 2 initial doses, then monthly booster doses; Fig. $1 A$ ) induced a substantial lesion of the LC, significantly reducing NET IR by $\sim 50 \%$ in both WT and P301S mice in all age groups (Fig. $1 B-E$ ). A two-way ANOVA at each age revealed a main effect of treatment ( 4 months, $F_{(1,41)}=78.19, p<0.0001 ; 6$ months, $F_{(1,28)}=40.13, p<0.0001 ; 10$ months, $F_{(1,37)}=27.22$, $p<0.0001$ ), but not genotype. Post hoc Sidak's tests showed marked loss of NET IR in DSP-4-lesioned animals compared with saline-treated animals (4 months, WT: $t_{(41)}=6.69, p<$ 0.0001, P301S: $t_{(41)}=5.79, p<0.0001 ; 6$ months, WT: $t_{(28)}=$ $4.55, p=0.0002$, P301S: $t_{(28)}=4.40, p=0.0003 ; 10$ months, WT: $t_{(37)}=4.42, p=0.0002$, P301S: $\left.t_{(37)}=3.01, p=0.0093\right)$. These results confirm that the LC lesions were successful, comparable with $\mathrm{LC}$ loss observed in $\mathrm{AD}$, and unaffected by the presence of mutant human tau.

NET IR in the hippocampus revealed that LC-derived noradrenergic fibers were also significantly reduced with DSP-4 lesions (Fig. 2A-D). Two-way ANOVA revealed a main effect of treat- 



Figure 2. DSP-4 reduces NET IR and tissue NE content in the hippocampus. $\boldsymbol{A}$, Representative immunofluorescence images. $\boldsymbol{B}-\boldsymbol{D}$, Quantification of NET IR in the hippocampus following saline or DSP-4 treatment in WT and P301S mice. E-G, Tissue NE concentrations in the hippocampus following saline or DSP-4 treatment in WT and P301S transgenic mice. Two-way ANOVA (treatment $X$ genotype) with Sidak's post hoc tests. Data are mean \pm SEM; $n=8-12$ per group. Scale bar, $200 \mu \mathrm{m}$. ${ }^{*} p<0.05$, compared with saline for that genotype. Hoechst, neuronal counterstain.

ment at each age (4 months, $F_{(1,43)}=61.96, p<0.0001 ; 6$ months, $F_{(1,37)}=37.71, p<0.0001 ; 10$ months, $F_{(1,41)}=34.31$, $p<0.0001$ ), but not genotype. Post hoc Sidak's tests showed that DSP-4-treated animals had a 75\%-95\% reduction in hippocampal NET IR compared with saline ( 4 months, WT: $t_{(43)}=5.79$, $p<0.0001$; P301S: $t_{(43)}=5.34, p<0.0001 ; 6$ months, WT: $t_{(37)}=$ 4.794, $p=0.0002$; P301S: $t_{(37)}=3.93, p=0.002 ; 10$ months, WT: $t_{(41)}=4.92, p<0.0001$; P301S: $\left.t_{(41)}=3.42, p=0.0074\right)$.

To confirm the functional loss of the NET-positive fibers on NE transmission capacity, we measure NE tissue content using HPLC followed by electrochemical detection (Fig. 2E-G). Twoway ANOVA revealed a main effect of treatment at 4 and 6 months $\left(4\right.$ months, $F_{(1,40)}=50.96, p<0.0001 ; 6$ months, $F_{(1,38)}=105.6, p<$ $0.0001)$ but not genotype. At 10 months, there was a main effect of treatment $\left(F_{(1,42)}=209.6, p<0.0001\right)$, genotype $\left(F_{(1,42)}=\right.$ $5.84, p=0.0201)$, and a treatment $\times$ genotype interaction $\left(F_{(1,42)}=\right.$ $4.88, p=0.0327)$. Post hoc Sidak's tests showed that all DSP-4 groups had lower hippocampal NE levels (60\%-92\% reduction) compared with saline-treated groups ( 4 months, WT: $t_{(40)}=$
4.30, $p=0.0006$; P301S: $t_{(40)}=5.80, p<0.0001 ; 6$ months, WT: $t_{(38)}=7.360, p<0.0001$; P301S: $t_{(38)}=7.20, p<0.0001 ; 10$ months, WT: $t_{(42)}=12.41, p<0.0001$; P301S: $t_{(42)}=8.29, p<$ $0.0001)$. At 10 months, saline-treated P301S mice also had $\sim 25 \%$ less hippocampal NE compared with saline-treated WT mice $\left(t_{(42)}=3.44, p=0.0079\right)$. Combined, these data indicate that (1) the presence of the P301S transgene did not affect the integrity of the noradrenergic system until 10 months, (2) DSP-4 treatment successfully lesioned LC cell bodies and projections, and (3) the extent of the lesions was comparable between genotypes.

\section{Neither P301S tau nor LC lesions alter circadian or} novelty-induced locomotor activity

To determine whether LC lesions impacted behavior, we examined mice in a series of tests to assess locomotor activity, anxiety, and cognitive performance. We first assessed $24 \mathrm{~h}$ circadian activity because $\mathrm{AD}$ patients can suffer from sleep disturbances (Bliwise, 2004), and circadian activity can be used as a proxy for sleep-wake cycles in mice (Richardson et al., 1985; Eckel-Mahan 
A

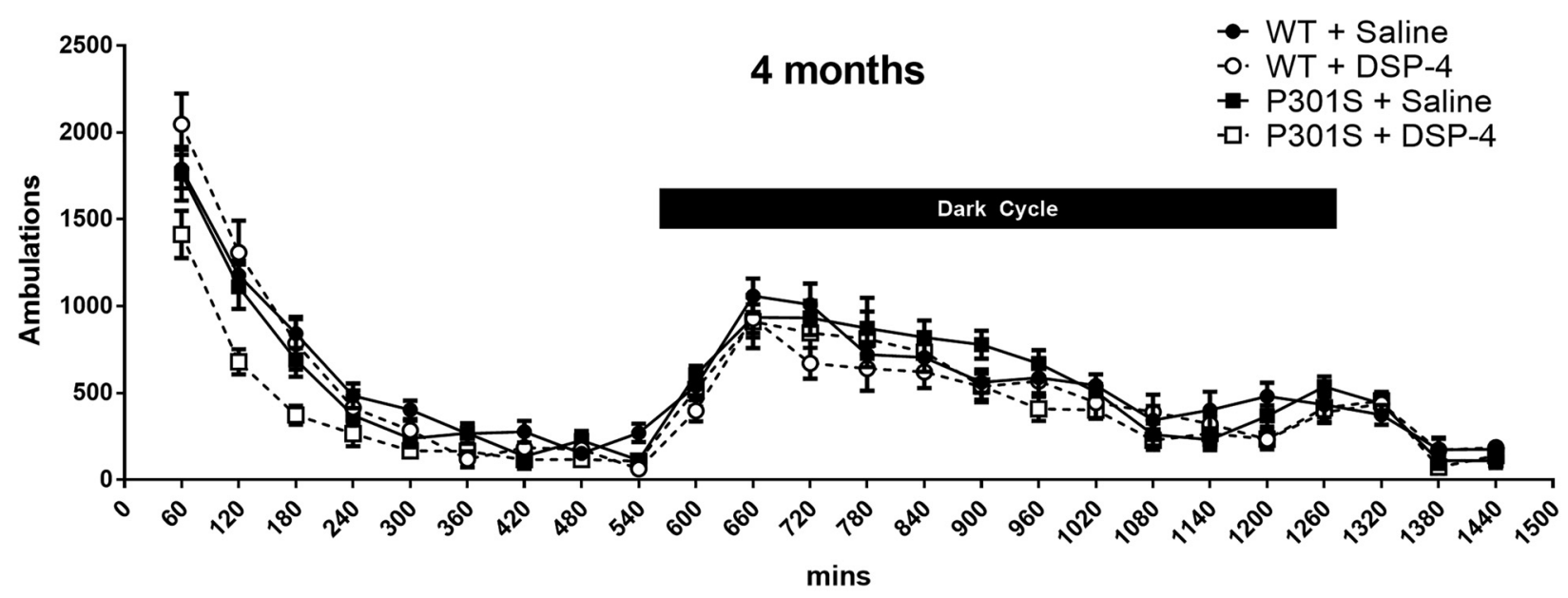

B
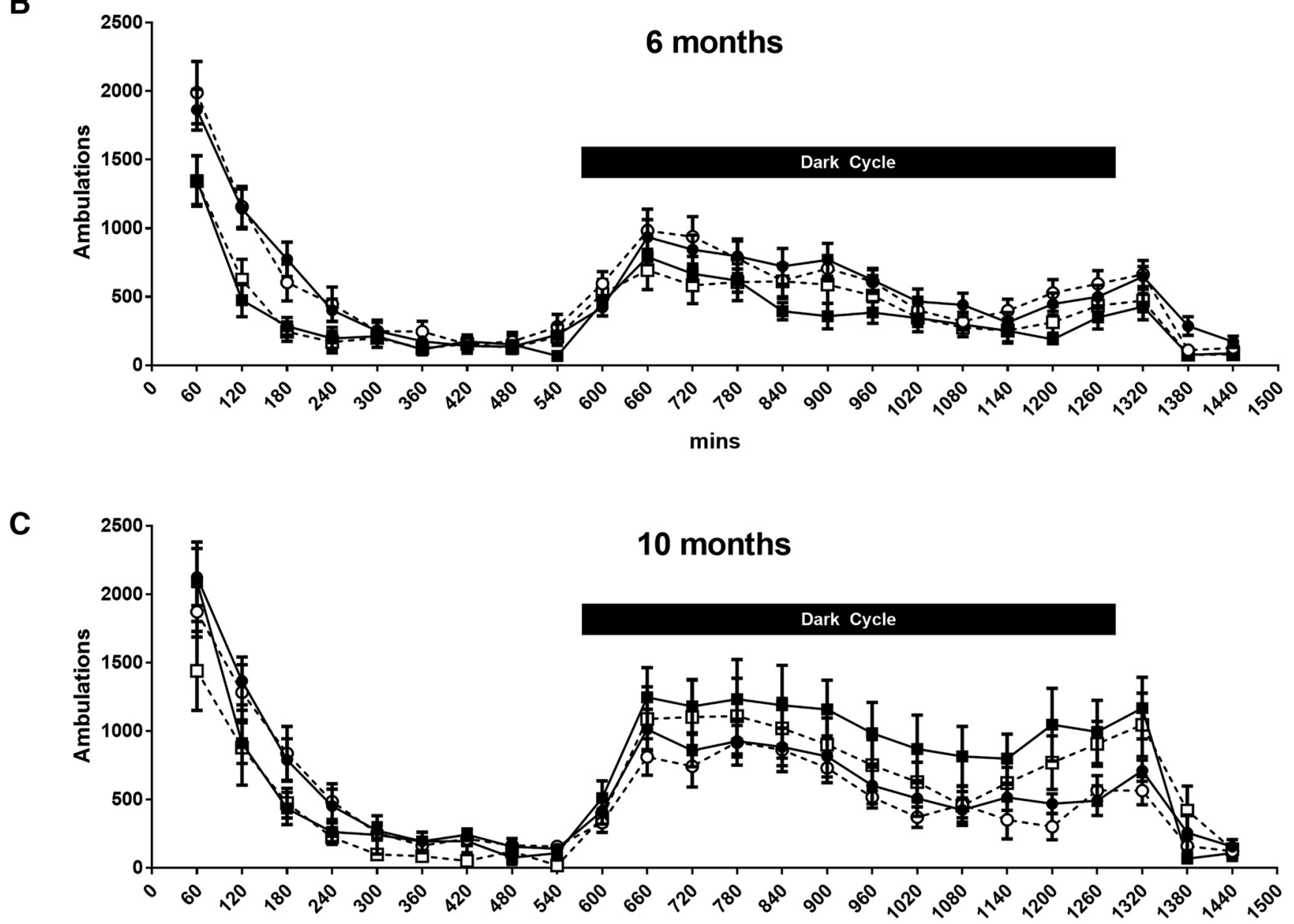

Figure 3. Neither LC degeneration nor P301S impacts circadian locomotor activity. Data are mean \pm SEM ambulations over $24 \mathrm{~h}$ in WT and P301S mice treated with saline or DSP-4; $n=7-12$ per group. $A$, 4 months; $B, 6$ months; $C$, 10 months.

and Sassone-Corsi, 2015; Musiek et al., 2015; Ray and Reddy, 2016). In addition, we wanted to account for any motor impairment that could impact performance in other tests and confound assessment of cognition.

Initially, high levels of ambulations were observed in all groups as they explored the novel test environment, which diminished over the next few hours as they habituated and assumed typical low light cycle activity (Fig. 3). There was a predictable increase in ambulations after the initiation of the dark cycle as the mice became active again, which extended a few hours into the beginning of the next light cycle before diminishing again. No significant differences in circadian activity were seen across the groups at any age, although there was a trend toward hypoactivity during the first few hours in the chamber at all ages and dark cycle hyperactivity at 10 months in both lesioned and unlesioned P301S mice compared with their WT counterparts. 
A

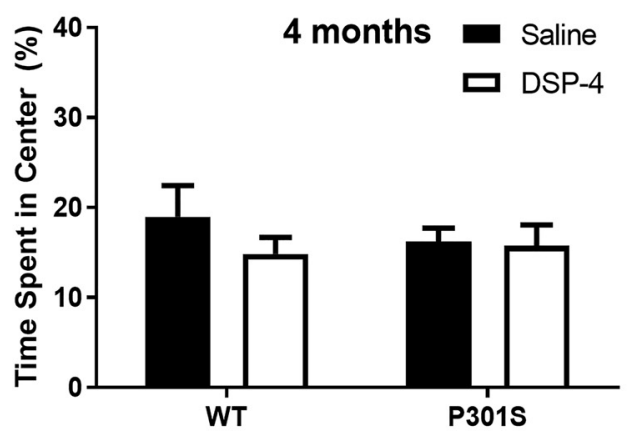

B

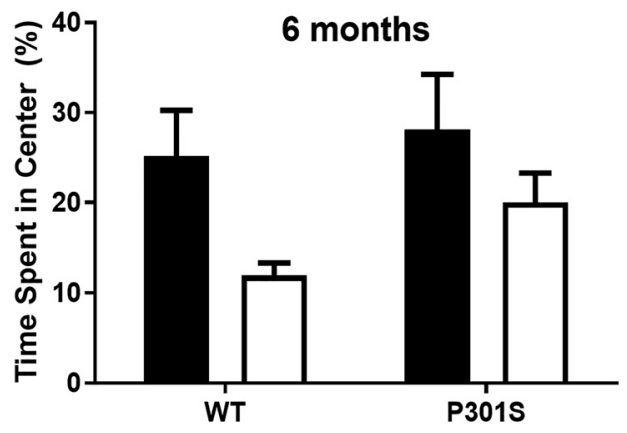

C

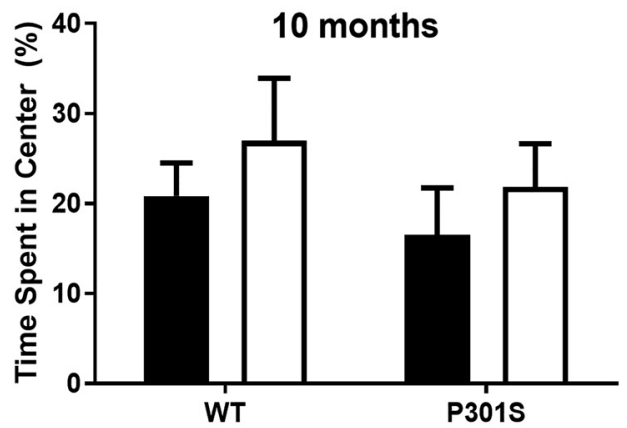

D

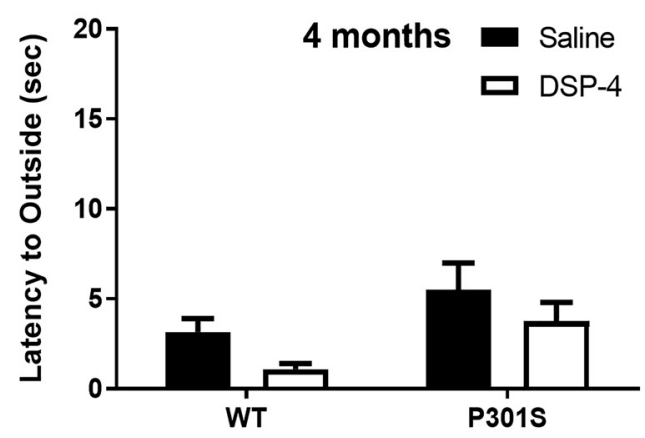

E

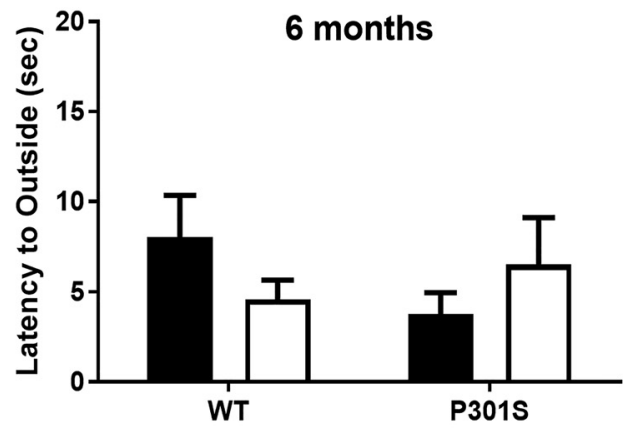

$\mathbf{F}$

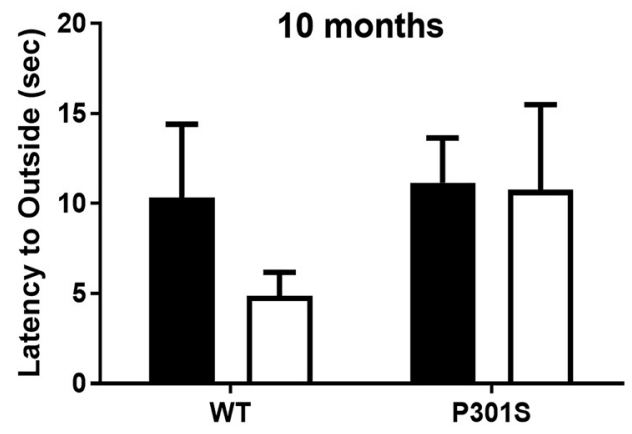

Figure 4. Neither LC degeneration nor P301S impacts anxiety-like behavior in the open field test. Data are mean \pm SEM $(\boldsymbol{A}-\boldsymbol{C})$ percentage time spent in center of the arena and $(\boldsymbol{D}-\boldsymbol{F})$ latency to leave the center of the arena in WT and P301S mice treated with saline or DSP-4; $n=7-12$ per group.

Neither P301S tau nor LC lesions alter anxiety-like behaviors in the open field task

Another phenotype consistent with NE dysfunction seen in Alzheimer's patients is anxiety (Seignourel et al., 2008; Li et al., 2014; Zhao et al., 2016); and like alterations in locomotor activity, an anxious phenotype could confound cognitive performance. We tested mice in an open field paradigm to probe for anxiety-like behaviors. There were no significant genotype or treatment differences at any age for either the percentage time spent in the center versus the outer ring (Fig. $4 A-C$ ) or the latency to escape from the center to the outer ring (Fig. $4 D-F$ ).

LC lesions exacerbate spatial learning and memory deficits in P301S mice

Salient features of AD patients include a tendency to get lost and trouble remembering even familiar places (Lithfous et al., 2013; Allison et al., 2016), largely due to the accumulation of pathology and neurodegeneration in the hippocampus (Leung et al., 2010; Nedelska et al., 2012). To probe for spatial learning and memory deficits, we tested mice in the Morris water maze, a hippocampaldependent task. Mice were trained with 4 trials daily over 5 consecutive days using surrounding spatial cues to learn the location of a hidden platform in a tank of water, and latency to find the platform and swim speed were recorded. On the sixth day, mice were returned to the maze without the platform for a probe trial, and the amount of time spent swimming in the previous quadrant location of the platform was recorded.

At 4 months, all groups showed learning over the 5 training days with significantly lower latencies to reach the platform compared with day 1 (Fig. 5A), but P301S mice with LC lesions learned more slowly. Two-way repeated-measures ANOVA revealed a main effect of time $\left(F_{(4,215)}=29.02, p<0.0001\right)$ and group $\left(F_{(3,215)}=\right.$ $7.40, p<0.0001)$. Post hoc Dunnett's tests showed that unlesioned WT $\left(t_{(215)}=2.84, p=0.0177\right)$ and P301S mice $\left(t_{(215)}=\right.$ $3.71, p=0.0010$ ) had significantly lower latencies to find the platform starting from day 2 of training compared with day 1 , with continued improvement in latencies over the rest of the training period. Lesioned WT mice showed significant learning by day $3\left(t_{(215)}=3.30, p=0.0043\right)$, also with similar improvements on later days. By contrast, DSP-4-treated P301S mice did not show significant learning until the final training day $\left(t_{(215)}=\right.$ 2.99, $p=0.0112)$. At 6 months, there were main effects again of time $\left(F_{(4,144)}=27.61, p<0.0001\right)$ and $\operatorname{group}\left(F_{(3,36)}=6.77, p=\right.$ 0.001 ) (Fig. $5 B$ ). Compared with day 1 , saline-treated WT mice showed significant learning by day $2\left(t_{(144)}=3.41, p=0.0031\right)$, and DSP-4-treated WT mice $\left(t_{(144)}=3.05, p=0.0099\right)$ and 


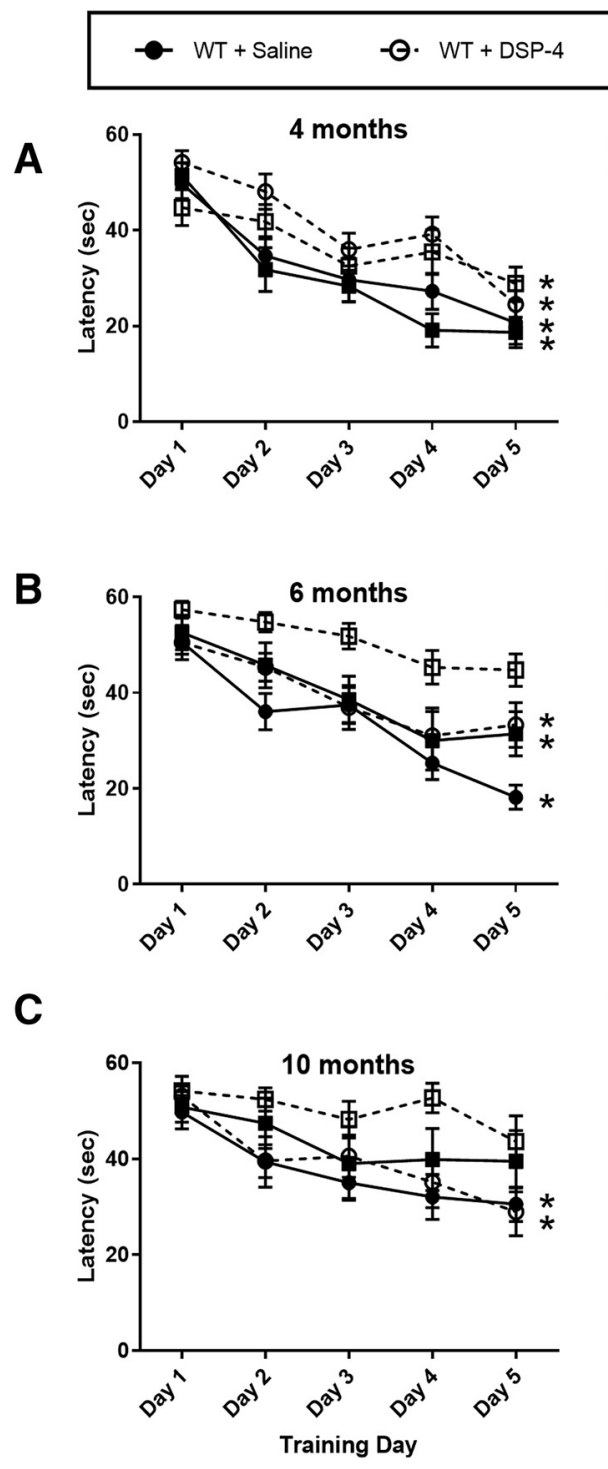
P301S + Saline
ㅂ. P301S + DSP-4
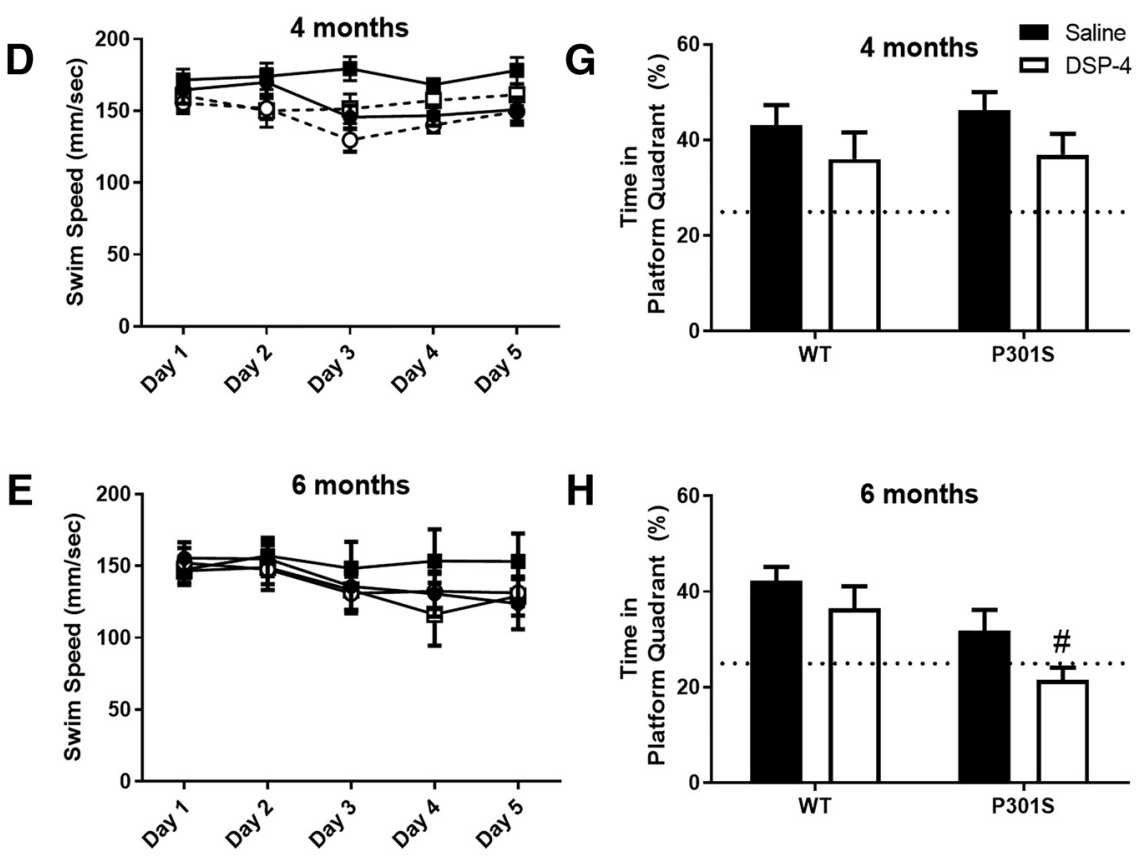

$\mathbf{F}$
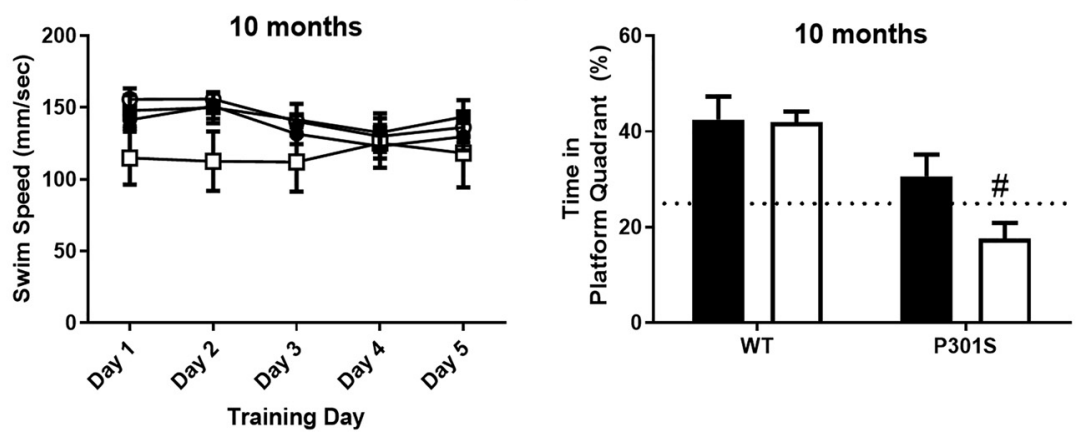

Figure 5. LC degeneration exacerbates spatial learning and memory in P3015 mice in the Morris water maze. Data are mean \pm SEM $(\boldsymbol{A}-\boldsymbol{C})$ latency to find the platform and $(\boldsymbol{D}-\boldsymbol{F})$ swim speed during $5 \mathrm{~d}$ of initial training in WT and P301S mice treated with saline or DSP-4. $N=8-12$ per group. Two-way repeated-measures ANOVA (group $\times$ training day) with Dunnett's post hoc tests. ${ }^{*} p<0.05$, compared with day 1 for that group. G-I, Data are mean \pm SEM percentage time spent swimming during the probe trial in the quadrant that previously contained the platform. Dotted line indicates the percentage time an animal would spend swimming in the correct quadrant by chance (25\%). $N=8-12$ per group. Two-way ANOVA (treatment $\times$ genotype) with Sidak's post hoc tests. ${ }^{\#} p<0.05$, compared with WT + saline.

unlesioned P301S mice $\left(t_{(144)}=2.86, p=0.0173\right)$ by day 3 , with similar improvements over the remaining training days. However, P301S mice with LC lesions never learned significantly compared with day 1 . At 10 months, there was a main effect of training day $\left(F_{(4,120)}=10.46, p<0.0001\right)$ (Fig. $5 C$ ). Unlesioned and lesioned WT mice still demonstrated learning (day $3, t_{(120)}=3.56, p=$ 0.0132 , and day $2, t_{(120)}=4.17, p=0.0076$, respectively), but neither group of P301S mice showed significant learning over the training period. There were no significant differences in swim speed across the groups at any age (Fig. $5 D-F$ ).

At 4 months, all groups performed similarly in the probe trial and spent $>25 \%$ of their time (i.e., greater than chance) swimming in the quadrant previously containing the platform (Fig. $5 G$ ), but at 6 months, the lesioned transgenics were impaired (Fig. $5 H$ ). A two-way ANOVA revealed a main effect of genotype $\left(F_{(1,37)}=10.53, p=0.0025\right)$ and treatment $\left(F_{(1,37)}=4.134, p=\right.$ 0.0492). Post hoc Sidak's tests showed that DSP-4-treated P301S animals spent significantly less time in the correct quadrant com- pared with unlesioned WT mice $\left(t_{(37)}=3.67, p=0.0046\right)$, whereas all other groups were not significantly different from each other. Similar results were observed at 10 months (Fig. 5I). There was a main effect of genotype $\left(F_{(1,33)}=21.94, p<0.0001\right)$, and again P301S mice with LC lesions were the only group significantly different from controls $\left(t_{(33)}=4.39, p=0.0007\right)$. Combined, these results indicate a synergistic impairment of both initial learning and memory recall between the presence of aberrant tau and LC degeneration.

\section{LC lesions weaken contextual, but not cued, fear memory in P301S mice}

We assessed the impact of LC lesions and P301S tau in a fear conditioning paradigm for two reasons. First, although contextual fear conditioning is hippocampal-dependent, similar to the Morris water maze, it is a measure of associative learning rather than spatial learning. Second, cued fear conditioning relies on associative learning but does not require an intact hippocampus. 


\section{Fear Conditioning}

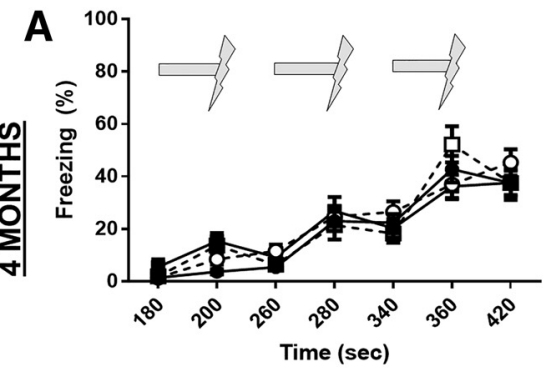

B

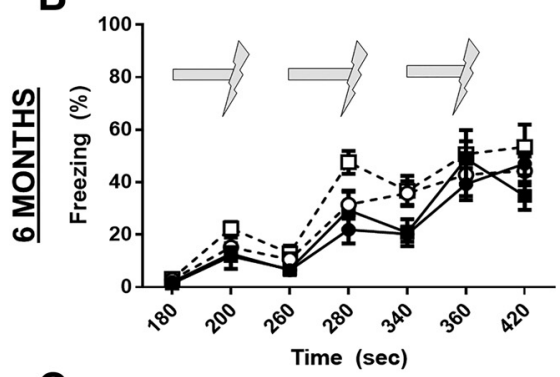

C

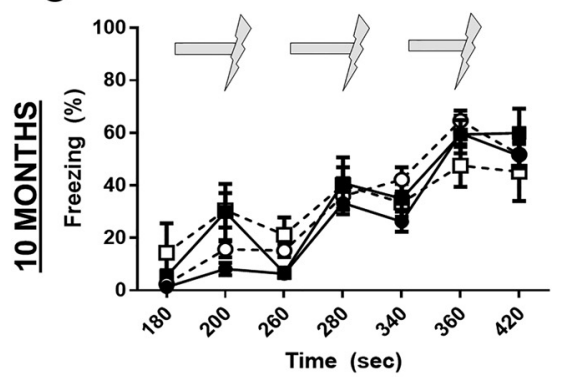

Contextual Fear Memory

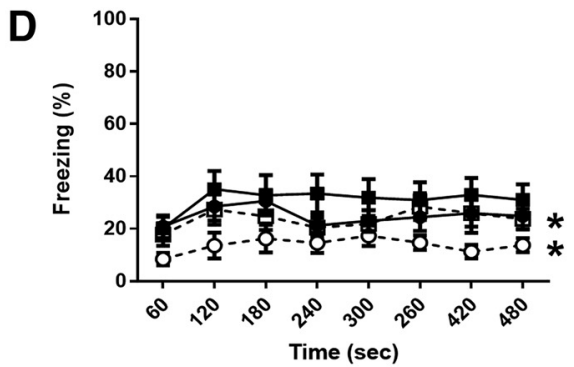

$\mathbf{E}$

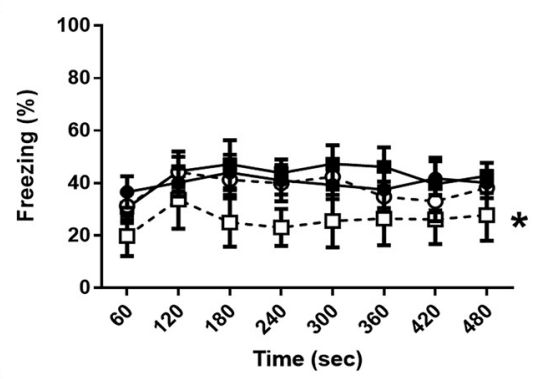

$\mathbf{F}$

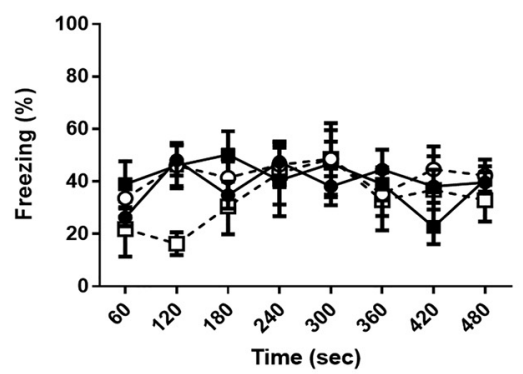

Cued Fear Memory

G

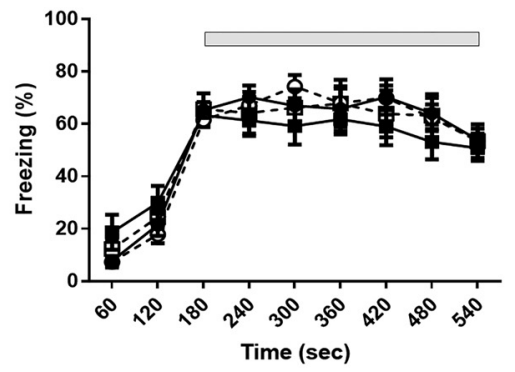

H

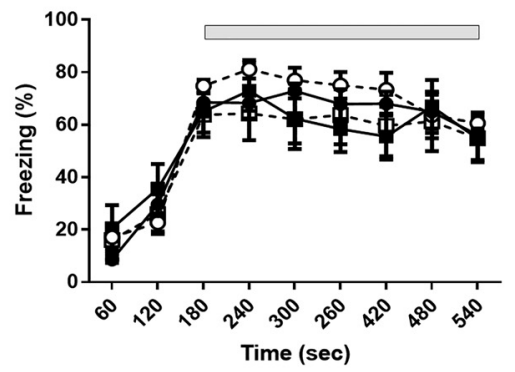

I

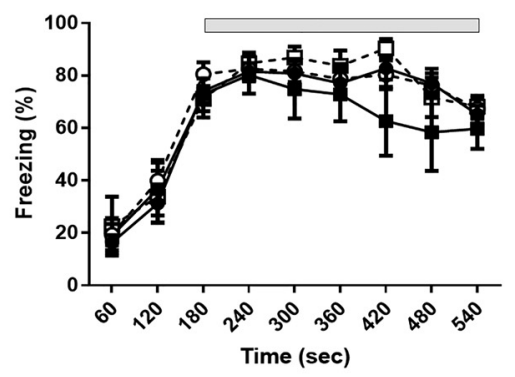

\begin{tabular}{|c|c|c|c|}
\hline$-W T+$ Saline & $\begin{array}{r}-\Theta \cdot \text { WT + DSP-4 } \\
\text { Tone }\end{array}$ & $\begin{array}{l}\text { P301S + Saline } \\
\text { Shock }\end{array}$ & -曰. P301S + DSP-4 \\
\hline
\end{tabular}

Figure 6. $\mathrm{LC}$ degeneration impairs contextual, but not cued fear memory in P3015 mice. Following 3 tone-shock pairings $(\boldsymbol{A}-\boldsymbol{C})$, fear behavior was recorded as percentage time spent freezing (mean \pm SEM) following reexposure to the shock-associated context $(\boldsymbol{D}-\boldsymbol{F})$ or tone $(\mathbf{G}-\boldsymbol{I})$ in WT and P301S treated with saline or DSP-4. $N=8-12$ per group. Two-way ANOVA (treatment $\times$ genotype) with Tukey's post hoc tests. ${ }^{*} p<0.05$, compared with WT + saline.

Thus, we could use these paradigms to assess both the categorical and neuroanatomical specificity of our Morris water maze results. Mice were placed individually in the fear conditioning chambers and exposed to 3 tone-shock pairings on day 1 . The following day, they were returned to the same chamber and contextual freezing was recorded. On the last day of the task, they were returned to the chamber with different contextual cues, and freezing in response to the tone was assessed.

During training, all mice showed freezing in response to the tone-shock pairings, with no differences between groups at 4 , 6, or 10 months (Fig. $6 A-C$ ). For contextual fear memory, a two-way ANOVA revealed a main effect of group at 4 months $\left(F_{(3,318)}=15.31, p<0.0001\right)$, and post hoc Tukey's tests showed that LC lesions significantly lowered freezing compared with their unlesioned counterparts for both WT $\left(t_{(318)}=3.98, p=\right.$ $0.0268)$ and P301S mice $\left(t_{(318)}=5.84, p=0.0003\right)$ (Fig. $\left.6 D\right)$. At 6 months, there was again a main effect of group $\left(F_{(3,255)}=7.579\right.$, $p<0.0001)$, and post hoc Tukey's tests revealed that DSP-4treated P301S mice had significantly less contextual freezing compared with all other groups (WT + saline, $t_{(255)}=5.71, p=$
0.0004; WT + DSP-4, $t_{(255)}=4.94, p=0.0032 ; \mathrm{P} 301 \mathrm{~S}+$ saline, $t_{(255)}=6.15, p=0.0001$ ) (Fig. $6 E$ ). At 10 months, there were no significant differences between groups (Fig. $6 F$ ). However, the 10 month data should be interpreted with caution because, at this age, many of the P301S mice had reduced overall activity in the test arena, which was difficult to parse out from bona fide "freezing." All groups displayed similarly high levels of cued freezing with the presentation of the tone during the third day of testing (Fig. $6 G-I$ ). These results demonstrate that $\mathrm{LC}$ lesions and P301S tau act synergistically to impair hippocampal-dependent contextual, but not hippocampal-independent cued, associative fear memory.

LC lesions decrease lifespan of P301S mice but do not alter physical neurodegenerative phenotypes

Because P301S mice age-related develop motor and postural phenotypes, we tested whether LC lesions exacerbated these physical manifestations of disease. While no gross locomotor deficits were observed at the beginning of behavioral testing at 10 months (Fig. $7 C$ ), many of the transgenic mice from the eldest age group began 
A

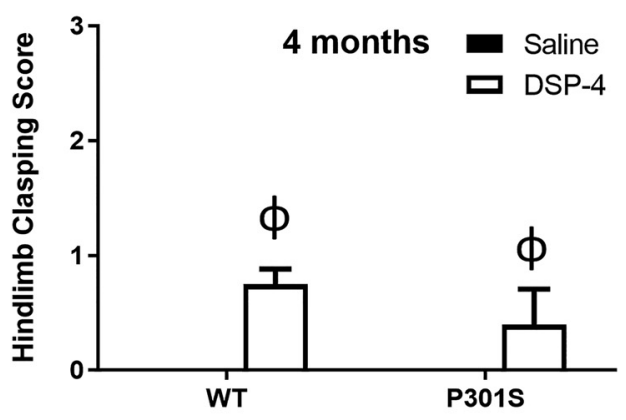

B

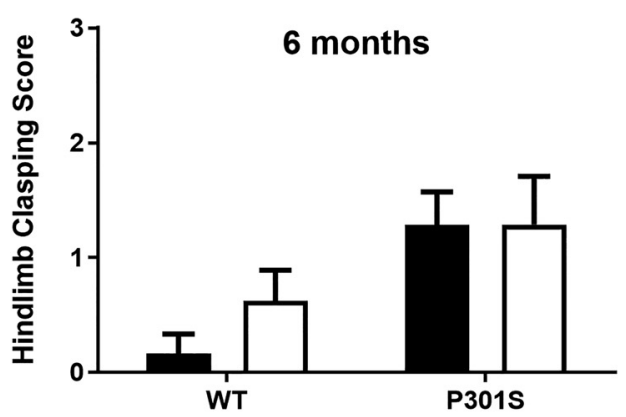

C

G

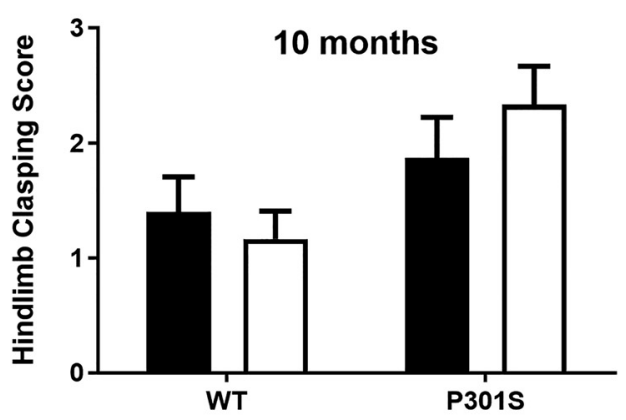

D

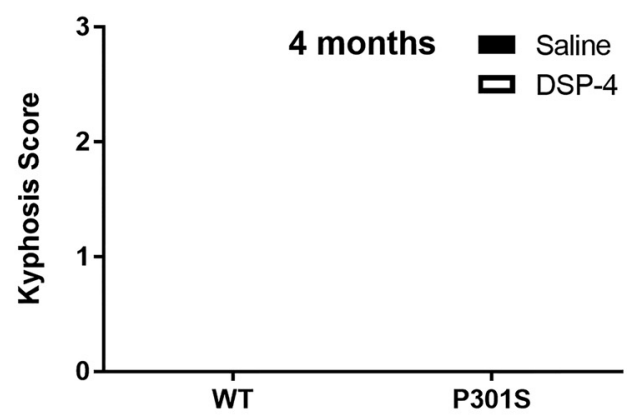

E

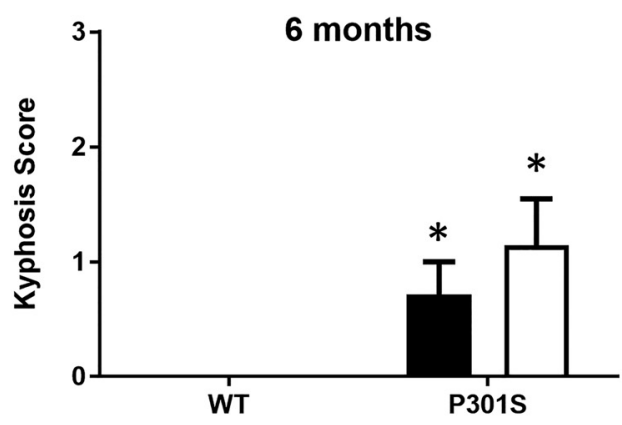

$\mathbf{F}$

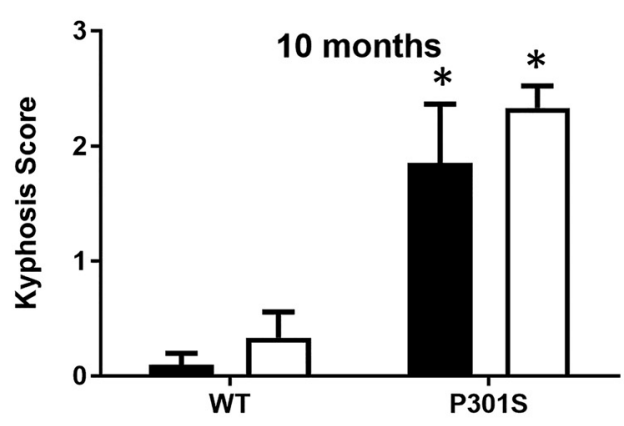

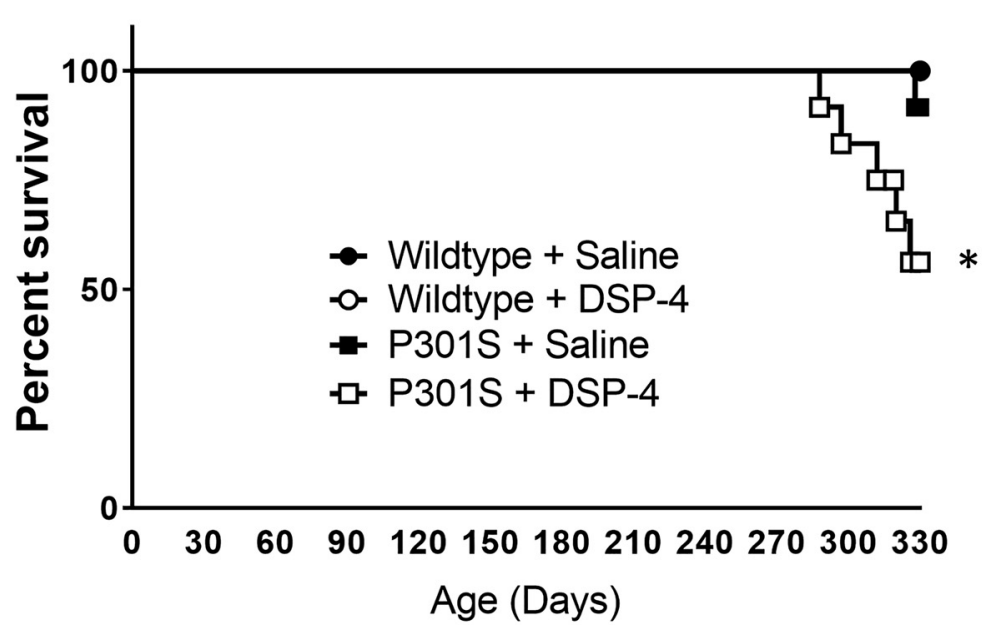

Figure 7. LC degeneration reduces survival in transgenic mice but does not alter physical neurodegenerative phenotypes. Quantification (mean \pm SEM) of $(\boldsymbol{A}-\mathbf{C})$ hindlimb clasping and $(\boldsymbol{D}-\boldsymbol{F})$ kyphosis. $N=6-12$ per group. Two-way ANOVA (treatment $\times$ genotype) with Tukey's post hoc tests. ${ }^{*} p<0.05$, compared with WT group with same treatment. ${ }^{\varphi} p<0.05$, compared with unlesioned group of the same genotype. G, Survival curve of WT and P301S mice treated with saline or DSP-4. N $=12$ per group. Log-rank (Mantel-Cox) test. ${ }^{*} p<0.05$, compared with all other groups.

to develop degenerative phenotypes by the end of this period $(\sim 11$ months). It is important to note that all behavioral tests, with the possible exception of fear conditioning (see above), were completed before the onset of these phenotypes. All mice were rated using a scale for severity of hindlimb clasping (Fig. 7A-C) and kyphosis (Fig. 7D-F), both physical phenotypes associated with neurodegeneration, especially in the spinal cord. A two-way ANOVA revealed only a main effect of treatment for hindlimb 
clasping $\left(F_{(1,36)}=10.95, p=0.0021\right)$ at 4 months, but only a main effect of genotype on both hindlimb clasping $\left(F_{(1,24)}=8.46\right.$, $p=0.0077)$ and kyphosis $\left(F_{(1,23)}=12.96, p=0.0015\right)$ at 6 months and 10 months (hindlimb clasping: $F_{(1,38)}=6.95, p=$ 0.0121; kyphosis: $\left.F_{(1,37)}=55.23, p<0.0001\right)$. In the older groups, both measures were generally more severe in P301S mice regardless of treatment.

Because AD is not only a disease of dementia, but also a leading cause of death (Alzheimer's Association, 2016), and P301S mice have a shorter lifespan than WT animals (Yoshiyama et al., 2007), we also determined whether DSP-4 lesions of the LC impacted the survival of P301S mice (Fig. 7G). No WT mice in the 10 month group (total of 11 for saline-treated and 12 for DSP-4treated) died by the end of behavioral testing, and only 1 of 12 saline-treated P301S mice was killed 1 week early (due to pronounced physical degenerative phenotype). By contrast, nearly half ( 5 of 12) of the P301S mice with LC lesions were found dead in their cages before the end of the experiment or had to be killed prematurely. Log-rank Mantel-Cox analysis showed that the DSP-4-treated P301S Kaplan-Meier survival curve was significantly different from saline-treated P301S mice $(p=0.0401)$ as well as both groups of WT animals (both $p=0.0113$ ).

\section{LC lesions increase neuroinflammation in P301S mice}

The hippocampus was evaluated for activated microglia (via Iba1 antibody; Fig. $8 A$ ) and astrocytes (via GFAP antibody; Fig. 9A) to assess neuroinflammation. For microglia, there were no effects of genotype or treatment at 4 months (Fig. $8 B$ ). At 6 months, a two-way ANOVA revealed only a main effect of genotype $\left(F_{(1,38)}=10.50, p=0.0025\right)$. Post hoc Tukey's tests showed that DSP-4-lesioned P301S mice had a small but significant increase in hippocampal Iba1 IR compared with both saline $\left(t_{(38)}=4.24\right.$, $p=0.0239)$ and DSP-4 $\left(t_{(38)}=4.27, p=0.0223\right)$ treated WT mice (Fig. $8 C$ ). At 10 months, a two-way ANOVA revealed a main effect of genotype $\left(F_{(1,43)}=76.38, p<0.0001\right)$, treatment $\left(F_{(1,43)}=11.01, p=0.0019\right)$, and a genotype $\times$ treatment interaction $\left(F_{(1,43)}=11.49, p=0.0015\right)$. Post hoc Tukey's tests showed that, while both saline-treated $\left(t_{(43)}=5.58, p=0.0016\right)$ and DSP-4-treated $\left(t_{(43)}=11.41, p<0.0001\right)$ P301S mice had elevated levels of Ibal compared with saline-treated WT, microglial activation was even greater in lesioned animals $\left(t_{(43)}=6.45, p=\right.$ 0.0002) (Fig. 8D).

For astrocytes, no genotype or treatment differences in GFAP IR were observed at 4 or 6 months (Fig. 9B, C). At 10 months, a two-way ANOVA revealed main effects of genotype $\left(F_{(1,39)}=\right.$ 96.29, $p<0.0001)$, treatment $\left(F_{(1,39)}=7.81, p=0.0080\right)$, and genotype $\times$ treatment interaction $\left(F_{(1,39)}=11.59, p=0.0015\right)$. Post hoc Tukey's tests showed that both saline $\left(t_{(39)}=6.64, p=\right.$ $0.0002)$ and DSP-4-treated $\left(t_{(39)}=12.48, p<0.0001\right)$ P301S mice had elevated levels of GFAP IR compared with salinetreated WT mice, but astrogliosis was significantly more pronounced in the lesioned animals $\left(t_{(39)}=6.26, p=0.0004\right)$ (Fig. $9 D)$. LC lesions had minimal impact on inflammation in the WT mice at all age groups, likely due to the month-long behavioral testing period after the final DSP-4 injection, before tissue harvesting. These data demonstrate an age-dependent increase in neuroinflammation specifically in P301S mice that was exacerbated by LC lesion.

\section{LC lesions promote neurodegeneration in the hippocampus of P301S mice}

To determine the impact of LC loss on neurodegeneration in this model of tauopathy, we assessed neuronal density in the hip- pocampus via IR for NeuN, a neuronal marker. No differences were observed between groups at 4 or 6 months (data not shown). At 10 months, lesioned P301S mice treated were the only group that showed significant neuronal loss (Fig. 10A). In the CA1 region, a two-way ANOVA revealed a main effect of genotype $\left(F_{(1,34)}=15.37, p=0.0004\right)$ and a genotype $\times$ treatment interaction $\left(F_{(1,34)}=8.38, p=0.0066\right)$. Post hoc Sidak's tests showed significant neuronal loss with DSP-4 compared with saline only in P301S mice $\left(t_{(34)}=2.52, p=0.0327\right)$ (Fig. $10 B$ ). In the CA3 region, a two-way ANOVA revealed a main effect of genotype $\left(F_{(1,34)}=20.54, p<0.0001\right)$, treatment $\left(F_{(1,34)}=6.07, p=\right.$ $0.0190)$, and a genotype $\times$ treatment interaction $\left(F_{(1,34)}=4.51\right.$, $p=0.0411)$, and again post hoc Sidak's tests showed significant neuronal loss only in DSP-4-treated P301S mice $\left(t_{(34)}=3.34, p=\right.$ 0.0041 ) (Fig. 10C). These results demonstrate that only a combination of P301S tau and LC degeneration results in hippocampal neuronal death up to 10 months of age.

\section{LC lesions augment hippocampal tau burden in P301S mice}

The extensive neuropathological and cognitive phenotypes of P301S mice are well established and have been attributed to the progressive accumulation of pathological tau throughout the brain (Yoshiyama et al., 2007; Takeuchi et al., 2011). To determine whether the exacerbation of phenotypes observed following LC lesions in the P301S mice was mediated by an increase in aberrant tau, we assessed whether lesioned animals displayed aggravated hippocampal tau pathology.

The P301S mutation makes tau prone to hyperphosphorylation, and the P301S mouse develops extensive pretangle tau pathology that can be visualized via a variety of phosphorylationdependent antibodies (Yoshiyama et al., 2007). The AT8 antibody detects phosphorylated serine and threonine residues at the 202 and 205 codons of tau, respectively, is commonly used as a marker of hyperphosphorylated tau in rodents and humans, and recognizes aberrant tau species in AD (Goedert et al., 1995). We used AT8 IR to assess the abundance of hyperphosphorylated tau in the hippocampus.

There was no AT8 IR above background in any WT mouse (lesioned or unlesioned) at any age (data not shown), consistent with previous reports that WT mouse tau is resistant to hyperphosphorylation (Clavaguera et al., 2009). In P301S mice, we saw weak AT8 IR beginning at 4 months, primarily in CA3 mossy fiber neurites (Fig. 11A). By 6 and 10 months, we observed more AT8 IR in the CA3 region, as well as in the CA1 and dentate gyrus (DG), including both cell body and neurite staining (Fig. 11A). Two-way ANOVA of the CA3 region revealed a main effect of age $\left(F_{(2,54)}=9.03, p=0.0004\right)$ but not treatment (Fig. 11B). The CA1 region revealed a similar pattern with a main effect of age $\left(F_{(2,54)}=\right.$ $15.77, p<0.0001$ ) but not treatment (Fig. 11D). However, in the DG region, there was a significant effect of age $\left(F_{(2,54)}=11,82\right.$, $p<0.0001)$ and an age $\times$ treatment interaction $\left(F_{(2,54)}=3.845\right.$, $p=0.0275)$. Post hoc Sidak's tests showed that lesioned P301S mice had significantly higher AT8 IR in the DG than unlesioned mice at 6 months $\left(t_{(54)}=2.96, p=0.0138\right)$ (Fig. 11C). There were no significant differences at the two other ages.

We next evaluated the hippocampus with another antibody (PHF1) that recognizes later-stage phosphorylation of serine residues at the 396 and 404 sites, indicative of conformational changes toward paired helical filaments. No PHF1 IR was observed in 4-month-old mice (data not shown), but it was detectable at 6 months and evident at 10 months (Fig. 12A). At 6 months, there was no significant difference in PHF1 IR in the 


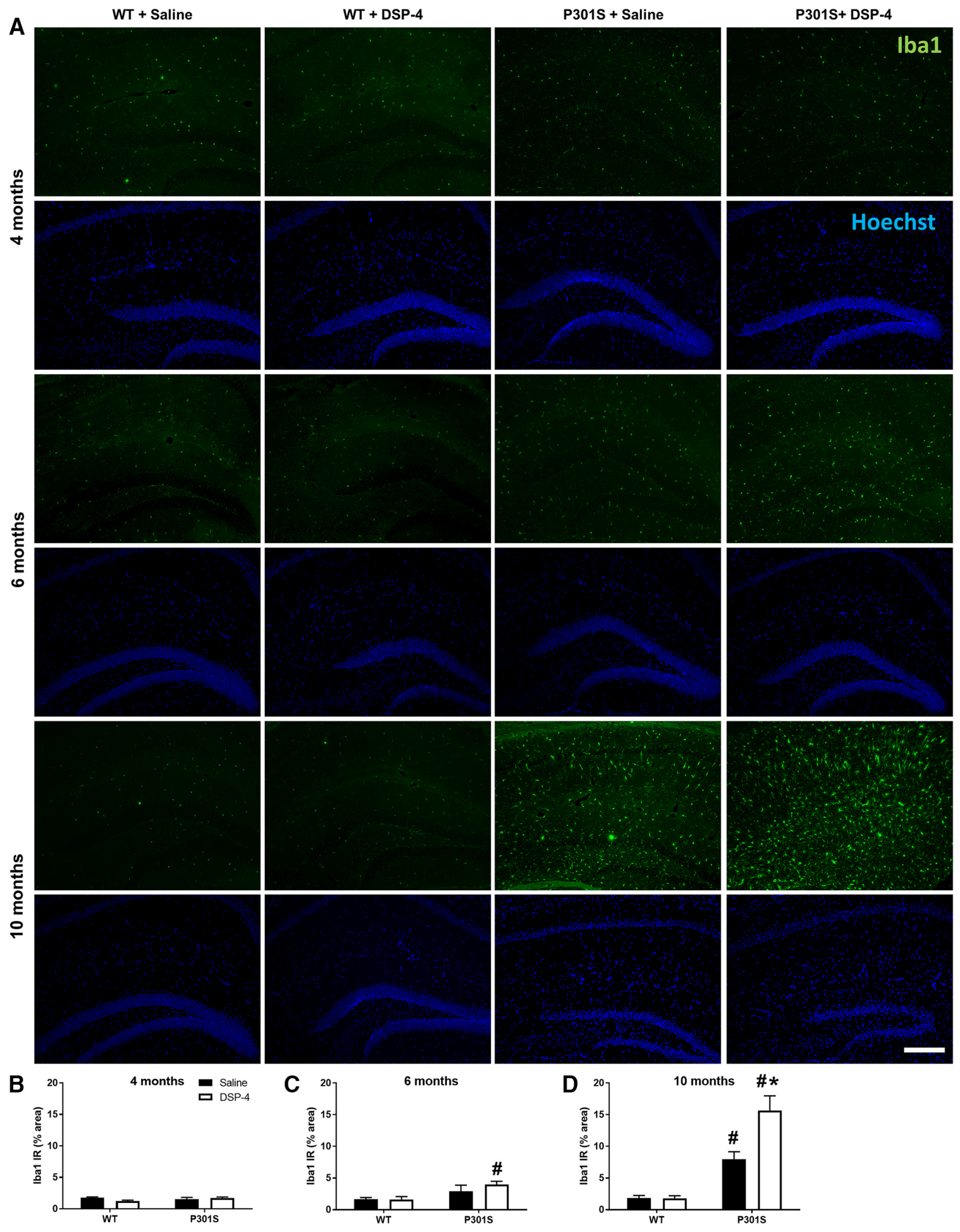

Figure 8. LC degeneration increases activated microglia in the hippocampus of P3015 mice. $A$, Representative immunofluorescence images. $B-D$, Quantification of Iba1 IR in the hippocampus of WT and P301S mice following saline or DSP-4 treatment. Data are mean \pm SEM; $n=8-12$ per group. Scale bar, $200 \mu \mathrm{m}$. Two-way ANOVA (treatment $\times$ genotype) with Tukey's post hoc tests. ${ }^{\#} p<0.05$, compared with WT + saline. ${ }^{*} p<0.05$, compared with P301S + saline. Iba1, microglia gene; Hoechst, neuronal counterstain. 


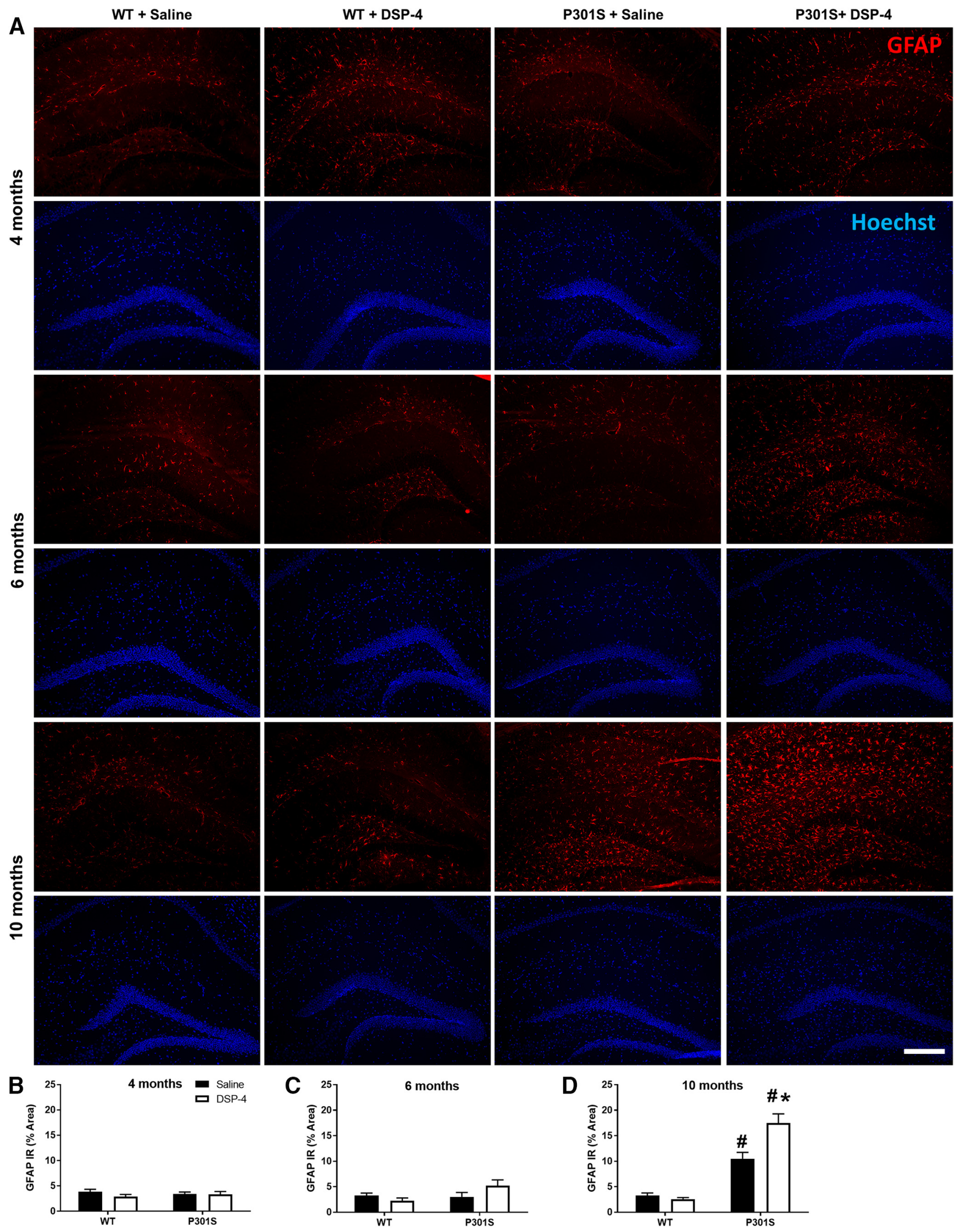

Figure 9. LC degeneration increases activated astrocytes in the hippocampus of P3015 mice. $A$, Representative immunofluorescence images. $\boldsymbol{B}-\boldsymbol{D}$, Quantification of GFAP IR in the hippocampus of WT and P3015 mice following saline or DSP-4 treatment. Two-way ANOVA (treatment $\times$ genotype) with Tukey's post hoc tests. Data are mean \pm SEM; $n=8-12$ per group. Scale bar, $200 \mu \mathrm{m}$. ${ }^{\#} p<0.05$, compared with WT + saline. ${ }^{*} p<0.05$, compared with P301S + saline. Hoechst, neuronal counterstain. 

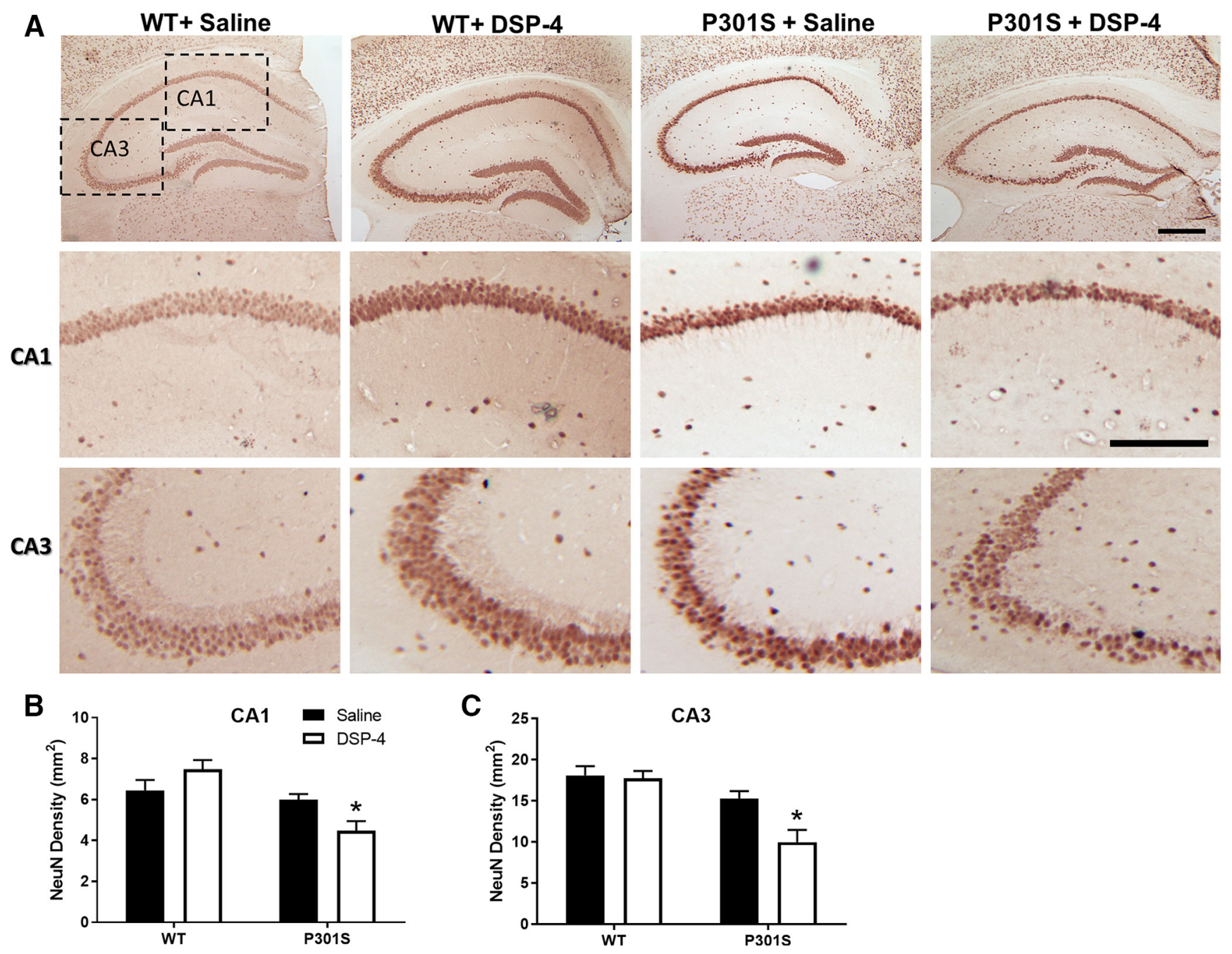

Figure 10. LC lesions promote neurodegeneration in the hippocampus of 10 month P3015 mice. Representative images $(\boldsymbol{A})$ and quantification of NeuN IR in the (B) CA1 and $(\boldsymbol{C})$ CA3 regions of the hippocampus of WT and P301S mice treated with saline or DSP-4. Two-way ANOVA (treatment $\times$ genotype) with Sidak's post hoc tests. Data are mean \pm SEM; $n=8-12$ per group. Scale bars: Top, $200 \mu \mathrm{m}$; Bottom, $100 \mu \mathrm{m} .{ }^{*} p<0.05$, compared with P301S + saline.

CA1 or DG region (Fig. 12B,C) between DSP-4-lesioned mice and controls, but in the $\mathrm{CA} 3$ region, a two-way ANOVA revealed there a main effect of treatment $\left(F_{(1,31)}=5.47, p=0.0260\right)$, but not age (Fig. 12D). Post hoc Sidak's tests showed significantly increased PHF1 IR in lesioned compared with unlesioned P301S mice $\left(t_{(14)}=2.51, p=0.0248\right)$. There were no differences in PHF1 IR at 10 months. Combined, these results indicate only a mild aggravation tau pathology by DSP-4 that is unlikely to completely explain the considerable worsening of cognitive impairment, neurodegeneration, and lethality caused by LC lesion.

\section{Discussion}

Extensive LC degeneration is nearly universal in $\mathrm{AD}$ (Bondareff et al., 1987; Chan-Palay and Asan, 1989; Lyness et al., 2003; Zarow et al., 2003; Haglund et al., 2006) and is among the earliest pathologies (Forno, 1966; Mann et al., 1980; Haglund et al., 2006), with LC abnormalities detectable years before neurocognitive signs (Grudzien et al., 2007; Braak and Del Tredici, 2011a, b; Braak et al., 2011; Andrés-Benito et al., 2017; Kelly et al., 2017; Theofilas et al., 2017). Importantly, several studies have revealed significant correlations between LC cell death/decreased cortical $\mathrm{NE}$ levels with severity and duration of dementia in $\mathrm{AD}$ (Yates et al., 1983; German et al., 1992), and LC integrity appears to encode cognitive reserve (Wilson et al., 2013). Thus, understanding the role of LC degeneration in $\mathrm{AD}$ pathogenesis could provide important insights for the underlying mechanisms of the disease, early detection, and new therapeutic avenues.

Experimental lesions of the LC exacerbate amyloid-mediated neuropathology and cognitive deficits in APP transgenic mice. Our study provides the first longitudinal analysis of how LC degeneration impacts tau-mediated impairment of learning and memory, neuropathology, and death. We demonstrate that LC lesions and associated depletion of hippocampal NE worsens hippocampal-based spatial and associative learning and memory impairment, increases neuroinflammation and neurodegeneration, and leads to earlier death in a mouse model of tauopathy. These data emphasize the important role of the LC for both primary $\mathrm{AD}$-associated neuropathologies: $\mathrm{A} \beta$ and tau.

The LC lesions appear to have the greatest impact on the cognitive deficits previously described for P301S mice (Yoshiyama et al., 2007; Davis et al., 2012; Iba et al., 2013). Although there were no effects of the transgene or DSP-4 alone in the Morris water maze at 6 months, the combination impaired both initial learn- 


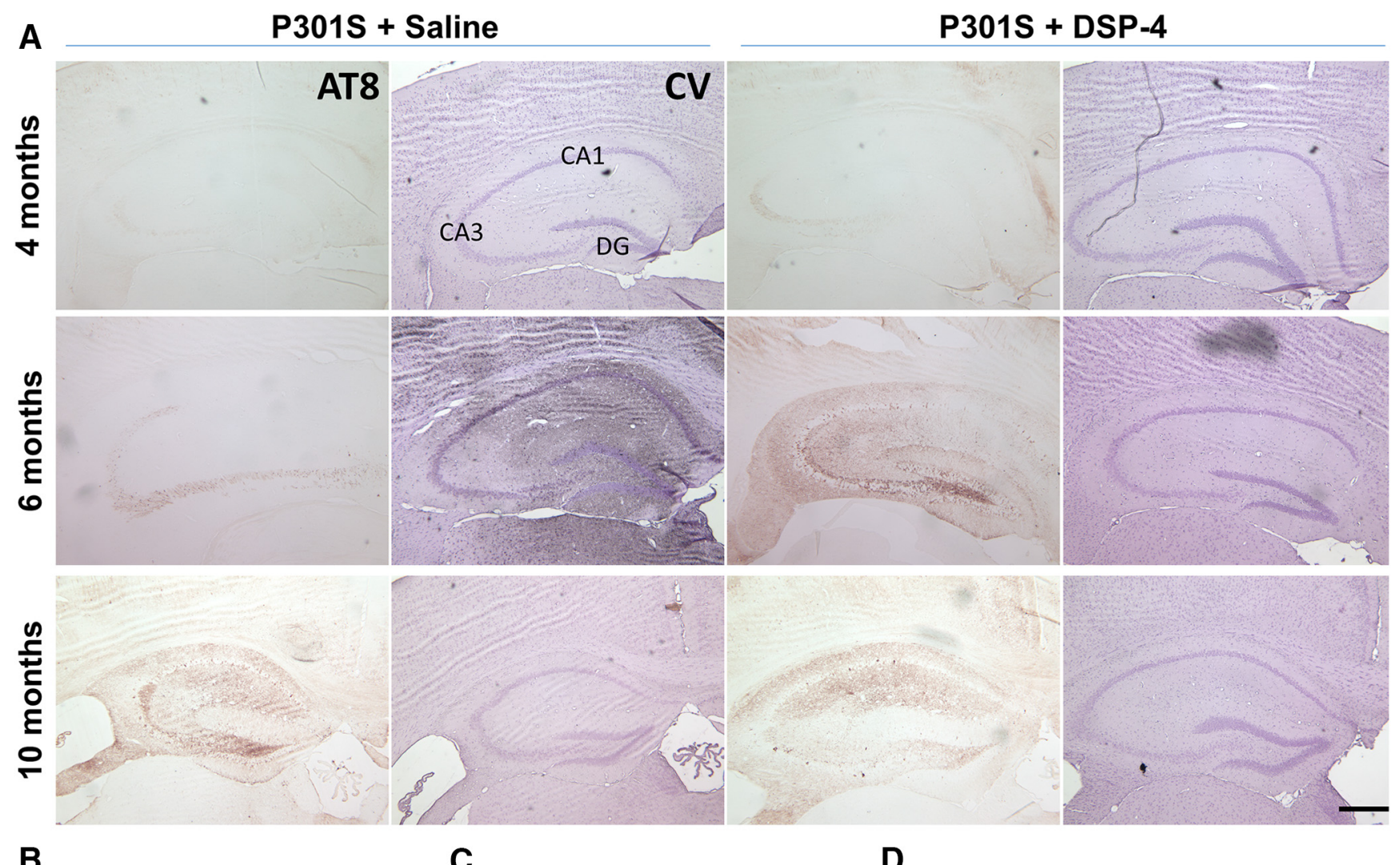

B

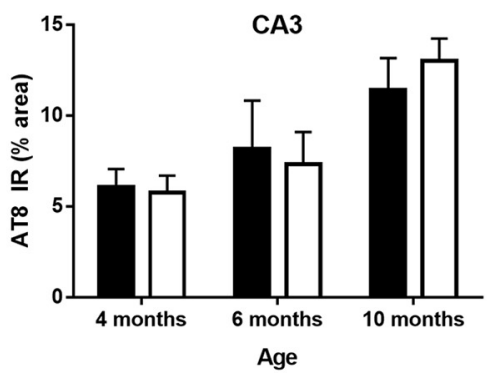

C

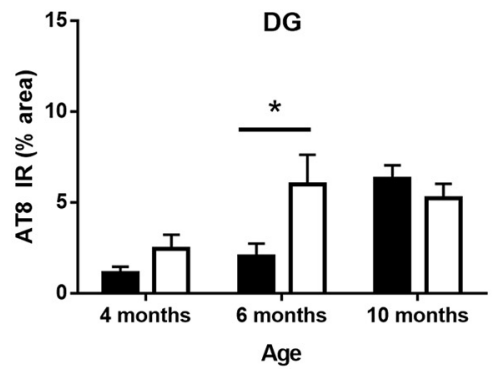

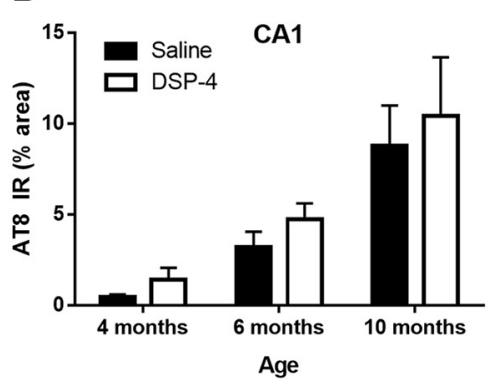

Figure 11. LC degeneration exacerbates hyperphosphorylated tau pathology in the dentate gyrus of P301S mice. Representative images of AT8 IR in the hippocampus of P301S mice following saline or DSP-4 treatment (A). Quantification of AT8 IR in CA3 (B), DG (C), and CA1 (D). Two-way ANOVA (treatment $\times$ genotype) with Sidak's post hoc tests. Data are mean \pm SEM; $n=8-12$ per group. Scale bar, $200 \mu \mathrm{m} .{ }^{*} p<0.05$. AT8, Phospho-tau (Ser202, Thr205), hyperphosphorylated tau; CV, cresyl violet, neuronal counterstain.

ing as well as reference memory recall in the probe trial. By 10 months, P301S mice with intact LCs caught up to their lesioned counterparts and exhibited similar learning deficits, but the synergy was still apparent for recall. The interaction between DSP-4 and P301S tau was also reminiscent of APP transgenic mice with LC lesions; synergistic deficits emerged by 6 months in the lesioned transgenics, and the effects of the lesion disappeared by 12 months when the transgenics with intact LC neurons caught up (Jardanhazi-Kurutz et al., 2010).

To further probe the functional consequences of NE depletion in the hippocampus of lesioned P301S mice, we used a fear conditioning paradigm that included both hippocampal (contextual) and nonhippocampal (cued) based memory components. All groups of mice displayed intact cued fear memory at every age tested, but there were significant differences in contextual fear memory. At 4 months, both WT and P301S mice with LC lesions performed significantly worse than their saline-treated counterparts. By 6 months, when DSP-4-treated P301S mice showed a significant deficit in the Morris water maze, there was also a selective and synergistic impairment in contextual fear memory in this group. At 10 months, all groups had similar levels of freezing as the other groups, but many of the P301S mice were beginning to show motor phenotypes and had reduced overall activity in the fear conditioning arena, which was difficult to parse out from bona fide "freezing."

P301S mice display physical neurodegenerative and motor phenotypes, such as kyphosis and hindlimb clasping, which eventually impact gross motor activity, eating, and drinking and lead to premature death (Takeuchi et al., 2011). DSP-4 lesions did not enhance these physical phenotypes, possibly because it is an LCspecific neurotoxin and spares the A5 and A7 noradrenergic cell groups that supply most of the NE to the spinal cord (Fritschy and Grzanna, 1989; Grzanna et al., 1989; Lyons et al., 1989). However, there was a profound deleterious effect of DSP-4 on the survival of P301S mice; almost half of the lesioned transgenics died by the end of the study, compared with only 1 of the saline-treated P301S mice. AD is lethal in humans; and although we did not determine the exact cause of death in our study, our results suggest that LC degeneration could contribute to $\mathrm{AD}$-associated mortality. 

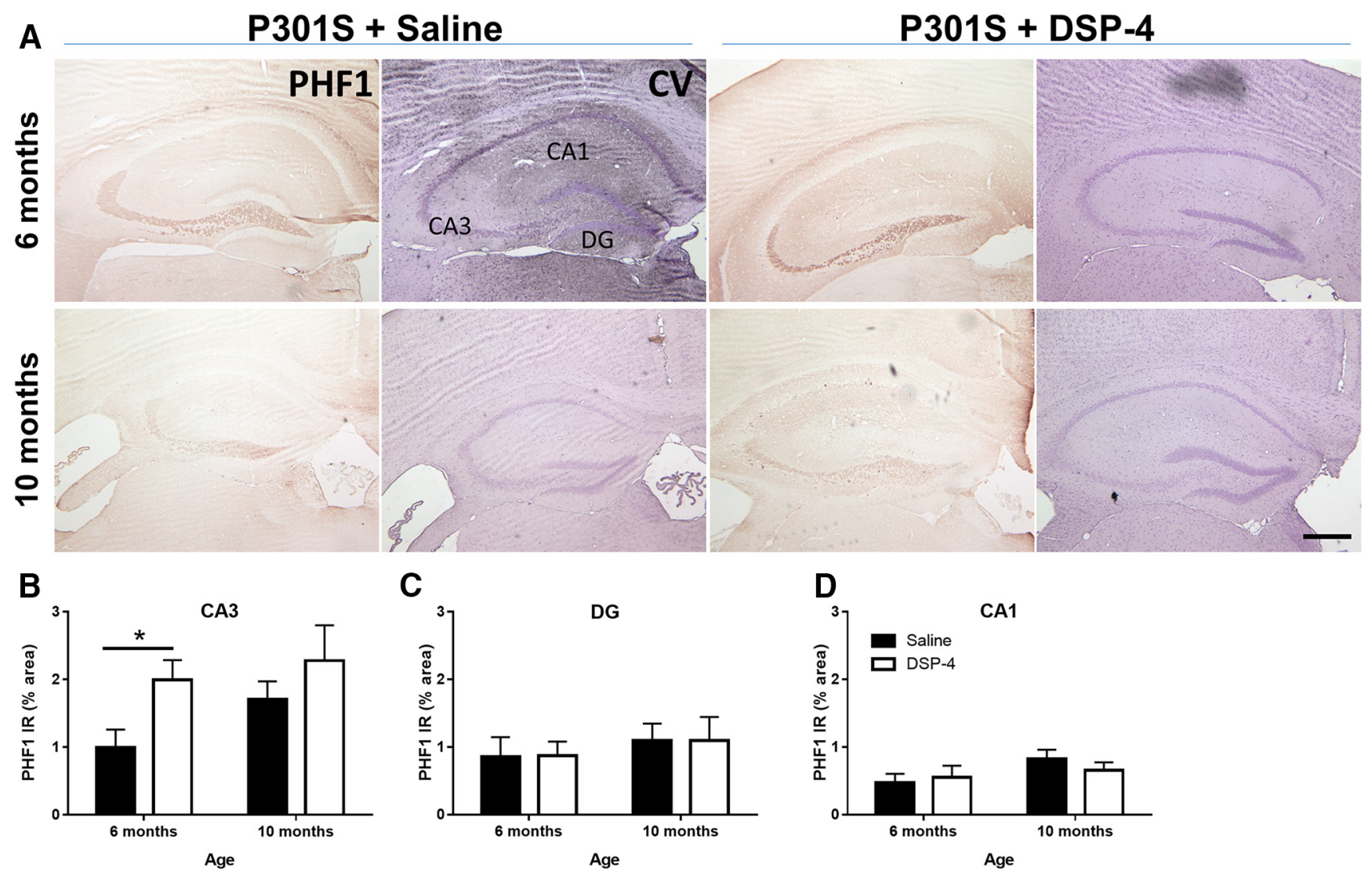

Figure 12. LC degeneration exacerbates paired helical tau pathology in CA3 of P3015 mice. Representative images of PHF1 IR in hippocampus of P301S mice following saline or DSP-4 treatment (A). Quantification of PHF1 IR in CA3 (B), DG (C), and CA1 (D). Two-way ANOVA (treatment $\times$ genotype) with Sidak's post hoc tests. Data are mean \pm SEM; $n=8-12$ per group. Scale bar, $200 \mu \mathrm{m}$. ${ }^{*} p<0.05$. PHF1, Phospho-tau (Ser396, Ser404), paired-helical filaments; CV, cresyl violet, neuronal counterstain.

Because of the conspicuous hippocampal-based learning and memory deficits produced by the lesions in P301S mice, we focused our neuropathological investigation to this brain region and hypothesized that there would be similar exacerbations of neuropathology. A similar pattern of synergy between LC lesions and tau accumulation was detected for two of the neuropathological characteristics of P301S mice: neuroinflammation and neurodegeneration. There was an increase in activated microglia and astrocytes in the hippocampus of lesioned P301S mice at 10 months, beyond the elevated levels produced by the tau transgene alone. The increased inflammation also may have contributed to the accelerated loss of hippocampal neurons following LC degeneration in the P301S mice. Because the enhanced neurodegeneration (as measured by loss of NeuN IR) was calculated by comparison with a baseline from unlesioned mice, it was internally controlled. However, NeuN antigenicity can be influenced by many factors, such as phosphorylation; thus, future investigations with volumetric analysis of whole hippocampus may provide more information on the extent of the neurodegeneration seen with this paradigm.

P301S-associated phenotypes are well correlated with the progressive accumulation of tau pathology within the brain, beginning first with hyperphosphorylated "pretangle" tau that aggregates into more misfolded forms, eventually resulting in the characteristic insoluble and Gallyas-positive neurofibrillary tangles (Yoshiyama et al., 2007). Because LC lesions increase amyloid burden in APP transgenic mice, we expected an equally robust exacerbation of tau pathology in the P301S animals. In our study, the CA3 region of the hippocampus appeared most vul- nerable; AT8-positive neuritic depositions in the mossy fiber pathway were present at 4 months. By 6 months, all regions showed intense AT8 pathology that filled neurites as well as cell bodies, and lesioned mice had elevated AT8 pathology in the DG. By 10 months, both lesioned and unlesioned P301S mice showed equivalent high levels of AT8 staining. We considered the possibility that lesioned P301S mice at this age had progressed to more severe tau pathology and assessed PHF1 IR, which detects a more advanced form of hyperphosphorylated tau. We found increased PHF1 pathology specifically in the CA3 region of lesioned mice at 6 months of age, but again these differences disappear by 10 months. While these results are consistent with the regional distribution of LC efferents to the hippocampus, which most densely innervate the DG and extend through the mossy fiber zones to parts of CA3, the exacerbation of tau pathology is modest and unlikely to account for the robust intensification of cognitive and neuropathological phenotypes seen with the lesions (Pickel et al., 1974; Swanson and Hartman, 1975; Loughlin et al., 1986; Oleskevich et al., 1989).

There are several ways to consider how LC degeneration might enhance P301S-induced pathology and cognitive deficits: (1) the loss of NE itself; (2) the loss of neuroprotective LCderived cotransmitters, such as BDNF and galanin; or (3) the physical process of LC fiber degeneration. While DSP-4 lesions accelerate both pathology and cognitive deficits in APP transgenic mice, genetic disruption of NE production or LC neuron specification that does not involve bona fide degeneration impacts cognition but not amyloid deposition (Hammerschmidt et al., 2013; Kummer et al., 2014). Chemogenetic activation of the 
LC rescues hippocampal-dependent learning and memory in a rat model of AD with both tau and $\beta$-amyloid pathology, suggesting that the acute neuromodulatory effects of NE may be more important than a chronic, neurotrophic influence on pathology (Rorabaugh et al., 2017). Future experiments using different approaches to disrupt LC neurons and NE transmission will be required to tease apart the mechanisms underlying enhancement of tau-mediated pathology and dementia.

The timing of P301S-induced phenotypes in our study conflicts with the original description of these transgenic mice; for example, cognitive impairment and mortality in our experiments were significantly delayed by comparison. Other groups have reported differences as well, which may be attributed to genetic drift and strain background (Taft et al., 2006; Yoshiyama et al., 2007; Davis et al., 2012; Iba et al., 2013; Kelmenson, 2016). Importantly, the shift in onset of behavioral phenotypes corresponds to the shift in pathology we observed. Thus, while the exact timing may be different between studies, analogous connections between the emergence of pathology and cognitive deficits persist.

The mechanisms underlying the interaction between LC degeneration and tau remain to be elucidated. However, combined with the literature, the observations from our study indicate that the LC can modulate both $\mathrm{A} \beta$ and tau models in the context of $\mathrm{AD}$ and significantly impact neuroinflammation, neurodegeneration, and cognitive impairment. Our results suggest that targeting the LC system to prevent degeneration and/or promote noradrenergic signaling may be an effective therapeutic strategy to combat the progression of neuropathology and dementia in AD. Genetic or pharmacological enhancement of NE transmission via increasing synthesis or blocking synaptic reuptake in APP transgenic mice ameliorates amyloid-related pathology and/or dementia (Kalinin et al., 2007; Heneka et al., 2010; Chalermpalanupap et al., 2013; Hammerschmidt et al., 2013; Kummer et al., 2014). The potential benefits of these approaches in the context of tau remain to be investigated.

\section{References}

Allison SL, Fagan AM, Morris JC, Head D (2016) Spatial navigation in preclinical Alzheimer's disease. J Alzheimers Dis 52:77-90. CrossRef Medline

Alzheimer's Association (2016) Alzheimer's disease facts and figures. Alzheimers Dement 12:459-509. Medline

Andrés-Benito P, Fernández-Dueñas V, Carmona M, Escobar LA, TorrejónEscribano B, Aso E, Ciruela F, Ferrer I (2017) Locus coeruleus at asymptomatic early and middle Braak stages of neurofibrillary tangle pathology. Neuropathol Appl Neurobiol 43:373-392. CrossRef Medline

Bliwise DL (2004) Sleep disorders in Alzheimer's disease and other dementias. Clin Cornerstone 6 [Suppl 1A]:S16-S28.

Bondareff W, Mountjoy CQ, Roth M, Rossor MN, Iversen LL, Reynolds GP, Hauser DL (1987) Neuronal degeneration in locus ceruleus and cortical correlates of Alzheimer disease. Alzheimer Dis Assoc Disord 1:256-262. CrossRef Medline

Braak H, Del Tredici K (2011a) The pathological process underlying Alzheimer's disease in individuals under thirty. Acta Neuropathol 121:171-181. CrossRef Medline

Braak H, Del Tredici K (2011b) Alzheimer's pathogenesis: is there neuron-toneuron propagation? Acta Neuropathol 121:589-595. CrossRef Medline

Braak H, Thal DR, Ghebremedhin E, Del Tredici K (2011) Stages of the pathologic process in Alzheimer disease: age categories from 1 to 100 years. J Neuropathol Exp Neurol 70:960-969. CrossRef Medline

Bretteville A, Marcouiller F, Julien C, El Khoury NB, Petry FR, Poitras I, Mouginot D, Lévesque G, Hébert SS, Planel E (2012) Hypothermiainduced hyperphosphorylation: a new model to study tau kinase inhibitors. Sci Rep 2:480. CrossRef Medline

Bugiani O (2000) FTDP-17: phenotypical heterogeneity within P301S. Ann Neurol 48:126. CrossRef Medline

Bugiani O, Murrell JR, Giaccone G, Hasegawa M, Ghigo G, Tabaton M,
Morbin M, Primavera A, Carella F, Solaro C, Grisoli M, Savoiardo M, Spillantini MG, Tagliavini F, Goedert M, Ghetti B (1999) Frontotemporal dementia and corticobasal degeneration in a family with a P301S mutation in tau. J Neuropathol Exp Neurol 58:667-677. CrossRef Medline

Carrettiero DC, Santiago FE, Motzko-Soares AC, Almeida MC (2015) Temperature and toxic tau in Alzheimer's disease: new insights. Temperature (Austin) 2:491-498. CrossRef Medline

Chalermpalanupap T, Kinkead B, Hu WT, Kummer MP, Hammerschmidt T, Heneka MT, Weinshenker D, Levey AI (2013) Targeting norepinephrine in mild cognitive impairment and Alzheimer's disease. Alzheimers Res Ther 5:21. CrossRef Medline

Chan-Palay V, Asan E (1989) Alterations in catecholamine neurons of the locus coeruleus in senile dementia of the Alzheimer type and in Parkinson's disease with and without dementia and depression. J Comp Neurol 287:373-392. CrossRef Medline

Clavaguera F, Bolmont T, Crowther RA, Abramowski D, Frank S, Probst A, Fraser G, Stalder AK, Beibel M, Staufenbiel M, Jucker M, Goedert M, Tolnay M (2009) Transmission and spreading of tauopathy in transgenic mouse brain. Nat Cell Biol 11:909-913. CrossRef Medline

Davis J, Maillet M, Miano JM, Molkentin JD (2012) Lost in transgenesis: a user's guide for genetically manipulating the mouse in cardiac research. Circ Res 111:761-777. CrossRef Medline

Eckel-Mahan K, Sassone-Corsi P (2015) Phenotyping circadian rhythms in mice. Curr Protoc Mouse Biol 5:271-281. CrossRef Medline

Feinstein DL, Kalinin S, Braun D (2016) Causes, consequences, and cures for neuroinflammation mediated via the locus coeruleus: noradrenergic signaling system. J Neurochem 139 [Suppl 2]:154-178. CrossRef Medline

Forno L (1966) Pathology of parkinsonism. J Neurosurg 2:266-271.

Fritschy JM, Grzanna R (1989) Immunohistochemical analysis of the neurotoxic effects of DSP-4 identifies two populations of noradrenergic axon terminals. Neuroscience 30:181-197. CrossRef Medline

Gannon M, Che P, Chen Y, Jiao K, Roberson ED, Wang Q (2015) Noradrenergic dysfunction in Alzheimer's disease. Front Neurosci 9:220. CrossRef Medline

German DC, Manaye KF, White CL 3rd, Woodward DJ, McIntire DD, Smith WK, Kalaria RN, Mann DM (1992) Disease-specific patterns of locus coeruleus cell loss. Ann Neurol 32:667-676. CrossRef Medline

Goedert M, Jakes R, Vanmechelen E (1995) Monoclonal antibody AT8 recognises tau protein phosphorylated at both serine 202 and threonine 205. Neurosci Lett 189:167-169. CrossRef Medline

Grudzien A, Shaw P, Weintraub S, Bigio E, Mash DC, Mesulam MM (2007) Locus coeruleus neurofibrillary degeneration in aging, mild cognitive impairment and early Alzheimer's disease. Neurobiol Aging 28:327-335. CrossRef Medline

Grzanna R, Berger U, Fritschy JM, Geffard M (1989) Acute action of DSP-4 on central norepinephrine axons: biochemical and immunohistochemical evidence for differential effects. J Histochem Cytochem 37:1435-1442. CrossRef Medline

Guérin D, Sacquet J, Mandairon N, Jourdan F, Didier A (2009) Early locus coeruleus degeneration and olfactory dysfunctions in Tg2576 mice. Neurobiol Aging 30:272-283. CrossRef Medline

Gulyas B, Brockschnieder D, Nag S, Pavlova E, Kasa P, Beliczai Z, Legradi A, Gulya K, Thiele A, Dyrks T, Halldin C (2010) The norepinephrine transporter (NET) radioligand (S,S)-[18F]FMeNER-D2 shows significant decreases in NET density in the human brain in Alzheimer's disease: a post-mortem autoradiographic study Neurochem Int 56:789-798. CrossRef Medline

Guyenet SJ, Furrer SA, Damian VM, Baughan TD, La Spada AR, Garden GA (2010) A simple composite phenotype scoring system for evaluating mouse models of cerebellar ataxia. J Vis Exp 39:1787. CrossRef Medline

Haglund M, Sjöbeck M, Englund E (2006) Locus ceruleus degeneration is ubiquitous in Alzheimer's disease: possible implications for diagnosis and treatment. Neuropathology 26:528-532. CrossRef Medline

Hammerschmidt T, Kummer MP, Terwel D, Martinez A, Gorji A, Pape HC, Rommelfanger KS, Schroeder JP, Stoll M, Schultze J, Weinshenker D, Heneka MT (2013) Selective loss of noradrenaline exacerbates early cognitive dysfunction and synaptic deficits in APP/PS1 mice. Biol Psychiatry 73:454-463. CrossRef Medline

Heneka MT, Ramanathan M, Jacobs AH, Dumitrescu-Ozimek L, BilkeiGorzo A, Debeir T, Sastre M, Galldiks N, Zimmer A, Hoehn M, Heiss WD, 
Klockgether T, Staufenbiel M (2006) Locus ceruleus degeneration promotes Alzheimer pathogenesis in amyloid precursor protein 23 transgenic mice. J Neurosci 26:1343-1354. CrossRef Medline

Heneka MT, Nadrigny F, Regen T, Martinez-Hernandez A, DumitrescuOzimek L, Terwel D, Jardanhazi-Kurutz D, Walter J, Kirchhoff F, Hanisch UK, Kummer MP (2010) Locus ceruleus controls Alzheimer's disease pathology by modulating microglial functions through norepinephrine. Proc Natl Acad Sci U S A 107:6058-6063. CrossRef Medline

Iba M, Guo JL, McBride JD, Zhang B, Trojanowski JQ, Lee VM (2013) Synthetic tau fibrils mediate transmission of neurofibrillary tangles in a transgenic mouse model of Alzheimer's-like tauopathy. J Neurosci 33: 1024-1037. CrossRef Medline

Iversen LL, Rossor MN, Reynolds GP, Hills R, Roth M, Mountjoy CQ, Foote SL, Morrison JH, Bloom FE (1983) Loss of pigmented dopamine-betahydroxylase positive cells from locus coeruleus in senile dementia of Alzheimer's type. Neurosci Lett 39:95-100. CrossRef Medline

Jalbert JJ, Daiello LA, Lapane KL (2008) Dementia of the Alzheimer type. Epidemiol Rev 30:15-34. CrossRef Medline

Jardanhazi-Kurutz D, Kummer MP, Terwel D, Vogel K, Dyrks T, Thiele A, Heneka MT (2010) Induced LC degeneration in APP/PS1 transgenic mice accelerates early cerebral amyloidosis and cognitive deficits. Neurochem Int 57:375-382. CrossRef Medline

Kalinin S, Gavrilyuk V, Polak PE, Vasser R, Zhao J, Heneka MT, Feinstein DL (2007) Noradrenaline deficiency in brain increases beta-amyloid plaque burden in an animal model of Alzheimer's disease. Neurobiol Aging 28: 1206-1214. CrossRef Medline

Kelly SC, He B, Perez SE, Ginsberg SD, Mufson EJ, Counts SE (2017) Locus coeruleus cellular and molecular pathology during the progression of Alzheimer's disease. Acta Neuropathol Commun 5:8. CrossRef Medline

Kelmenson P (2016) Maybe it's not you, maybe it's your mice! The Jackson Laboratory [Blog post]. Available online at: https://www.jax.org/news-andinsights/jax-blog/2016/august/maybe-its-not-you. Accessed November 15, 2017.

Kummer MP, Hammerschmidt T, Martinez A, Terwel D, Eichele G, Witten A, Figura S, Stoll M, Schwartz S, Pape HC, Schultze JL, Weinshenker D, Heneka MT, Urban I (2014) Ear2 deletion causes early memory and learning deficits in APP/PS1 mice. J Neurosci 34:8845-8854. CrossRef Medline

Leung KK, Barnes J, Ridgway GR, Bartlett JW, Clarkson MJ, Macdonald K, Schuff N, Fox NC, Ourselin S (2010) Automated cross-sectional and longitudinal hippocampal volume measurement in mild cognitive impairment and Alzheimer's disease. Neuroimage 51:1345-1359. CrossRef Medline

Li XL, Hu N, Tan MS, Yu JT, Tan L (2014) Behavioral and psychological symptoms in Alzheimer's disease. Biomed Res Int 2014:927804. CrossRef Medline

Lithfous S, Dufour A, Després O (2013) Spatial navigation in normal aging and the prodromal stage of Alzheimer's disease: insights from imaging and behavioral studies. Ageing Res Rev 12:201-213. CrossRef Medline

Liu L, Luo S, Zeng L, Wang W, Yuan L, Jian X (2013) Degenerative alterations in noradrenergic neurons of the locus coeruleus in Alzheimer's disease. Neural Regen Res 8:2249-2255. CrossRef Medline

Liu Y, Yoo MJ, Savonenko A, Stirling W, Price DL, Borchelt DR, Mamounas L, Lyons WE, Blue ME, Lee MK (2008) Amyloid pathology is associated with progressive monoaminergic neurodegeneration in a transgenic mouse model of Alzheimer's disease. J Neurosci 28:1380513814. CrossRef Medline

Lossos A, Reches A, Gal A, Newman JP, Soffer D, Gomori JM, Boher M, Ekstein D, Biran I, Meiner Z, Abramsky O, Rosenmann H (2003) Frontotemporal dementia and parkinsonism with the P301S tau gene mutation in a Jewish family. J Neurol 250:733-740. CrossRef Medline

Loughlin SE, Foote SL, Grzanna R (1986) Efferent projections of nucleus locus coeruleus: morphologic subpopulations have different efferent targets. Neuroscience 18:307-319. CrossRef Medline

Lyness SA, Zarow C, Chui HC (2003) Neuron loss in key cholinergic and aminergic nuclei in Alzheimer disease: a meta-analysis. Neurobiol Aging 24:1-23. CrossRef Medline

Lyons WE, Fritschy JM, Grzanna R (1989) The noradrenergic neurotoxin DSP-4 eliminates the coeruleospinal projection but spares projections of the A5 and A7 groups to the ventral horn of the rat spinal cord. J Neurosci 9:1481-1489. Medline

Mann DM (1983) The locus coeruleus and its possible role in ageing and degenerative disease of the human central nervous system. Mech Ageing Dev 23:73-94. CrossRef Medline

Mann DM, Lincoln J, Yates PO, Stamp JE, Toper S (1980) Changes in the monoamine containing neurones of the human CNS in senile dementia. Br J Psychiatry 136:533-541. CrossRef Medline

Mather M, Harley CW (2016) The locus coeruleus: essential for maintaining cognitive function and the aging brain. Trends Cogn Sci 20:214-226. CrossRef Medline

Musiek ES, Xiong DD, Holtzman DM (2015) Sleep, circadian rhythms, and the pathogenesis of Alzheimer disease. Exp Mol Med 47:e148. CrossRef Medline

Nedelska Z, Andel R, Laczó J, Vlcek K, Horinek D, Lisy J, Sheardova K, Bures J, Hort J (2012) Spatial navigation impairment is proportional to right hippocampal volume. Proc Natl Acad Sci U S A 109:2590-2594. CrossRef Medline

Oddo S, Caccamo A, Shepherd JD, Murphy MP, Golde TE, Kayed R, Metherate R, Mattson MP, Akbari Y, LaFerla FM (2003) Triple-transgenic model of Alzheimer's disease with plaques and tangles: intracellular Abeta and synaptic dysfunction. Neuron 39:409-421. CrossRef Medline

Oleskevich S, Descarries L, Lacaille JC (1989) Quantified distribution of the noradrenaline innervation in the hippocampus of adult rat. J Neurosci 9:3803-3815. Medline

Pickel VM, Segal M, Bloom FE (1974) A radioautographic study of the efferent pathways of the nucleus locus coeruleus. J Comp Neurol 155:1542. CrossRef Medline

Planel E, Richter KE, Nolan CE, Finley JE, Liu L, Wen Y, Krishnamurthy P, Herman M, Wang L, Schachter JB, Nelson RB, Lau LF, Duff KE (2007) Anesthesia leads to tau hyperphosphorylation through inhibition of phosphatase activity by hypothermia. J Neurosci 27:3090-3097. CrossRef Medline

Ray S, Reddy AB (2016) Cross-talk between circadian clocks, sleep-wake cycles, and metabolic networks: dispelling the darkness. Bioessays 38: 394-405. CrossRef Medline

Rey NL, Jardanhazi-Kurutz D, Terwel D, Kummer MP, Jourdan F, Didier A, Heneka MT (2012) Locus coeruleus degeneration exacerbates olfactory deficits in APP/PS1 transgenic mice. Neurobiol Aging 33:426e1-11. CrossRef Medline

Richardson GS, Moore-Ede MC, Czeisler CA, Dement WC (1985) Circadian rhythms of sleep and wakefulness in mice: analysis using long-term automated recording of sleep. J Physiol 248:R320-R330. Medline

Rorabaugh JM, Chalermpalanupap T, Botz-Zapp C, Fu V, Lembeck N, Cohen RM, Weinshenker D (2017) Chemogenetic locus coeruleus activation restores reversal learning in a rat model of Alzheiemer's disease. Brain 40:3023-3038. CrossRef Medline

Seignourel PJ, Kunik ME, Snow L, Wilson N, Stanley M (2008) Anxiety in dementia: a critical review. Clin Psychol Rev 28:1071-1082. CrossRef Medline

Swanson LW, Hartman BK (1975) The central adrenergic system: an immunofluorescence study of the location of cell bodies and their efferent connections in the rat utilizing dopamine-beta-hydroxylase as a marker. J Comp Neurol 163:467-505. CrossRef Medline

Szabadi E (2013) Functional neuroanatomy of the central noradrenergic system. J Psychopharmacol 27:659-693. CrossRef Medline

Taft RA, Davisson M, Wiles MV (2006) Know thy mouse. Trends Genet 22:649-653. CrossRef Medline

Takeuchi H, Iba M, Inoue H, Higuchi M, Takao K, Tsukita K, Karatsu Y, Iwamoto Y, Miyakawa T, Suhara T, Trojanowski JQ, Lee VM, Takahashi R (2011) P301S mutant human tau transgenic mice manifest early symptoms of human tauopathies with dementia and altered sensorimotor gating. PLoS One 6:e21050. CrossRef Medline

Theofilas P, Ehrenberg AJ, Dunlop S, Di Lorenzo Alho AT, Nguy A, Leite RE, Rodriguez RD, Mejia MB, Suemoto CK, Ferretti-Rebustini RE, Polichiso L, Nascimento CF, Seeley WW, Nitrini R, Pasqualucci CA, Jacob Filho W, Rueb U, Neuhaus J, Heinsen H, Grinberg LT (2017) Locus coeruleus volume and cell population changes during Alzheimer's disease progression: a stereological study in human postmortem brains with potential implication for early-stage biomarker discovery. Alzheimers Dement 13: 236-246. CrossRef Medline

Weinshenker D (2008) Functional consequences of locus coeruleus degeneration in Alzheimer's disease. Curr Alzheimer Res 5:342-345. CrossRef Medline

Wilson RS, Nag S, Boyle PA, Hizel LP, Yu L, Buchman AS, Schneider JA, 
Bennett DA (2013) Neural reserve, neuronal density in the locus ceruleus, and cognitive decline. Neurology 80:1202-1208. CrossRef Medline

Yasuda M, Yokoyama K, Nakayasu T, Nishimura Y, Matsui M, Yokoyama T, Miyoshi K, Tanaka C (2000) A Japanese patient with frontotemporal dementia and parkinsonism by a tau P301S mutation. Neurology 55: 1224-1227. CrossRef Medline

Yates CM, Simpson J, Gordon A, Maloney AF, Allison Y, Ritchie IM, Urquhart A (1983) Catecholamines and cholinergic enzymes in pre-senile and senile Alzheimer-type dementia and Down's syndrome. Brain Res 280:119-126. CrossRef Medline

Yoshiyama Y, Higuchi M, Zhang B, Huang SM, Iwata N, Saido TC, Maeda J, Suhara T, Trojanowski JQ, Lee VM (2007) Synapse loss and microglial activation precede tangles in a P301S tauopathy mouse model. Neuron 53:337-351. CrossRef Medline

Zarow C, Lyness SA, Mortimer JA, Chui HC (2003) Neuronal loss is greater in the locus coeruleus than nucleus basalis and substantia nigra in Alzheimer and Parkinson diseases. Arch Neurol 60:337-341. CrossRef Medline

Zhao QF, Tan L, Wang HF, Jiang T, Tan MS, Tan L, Xu W, Li JQ, Wang J, Lai TJ, Yu JT (2016) The prevalence of neuropsychiatric symptoms in Alzheimer's disease: systematic review and meta-analysis. J Affect Disord 190:264-271. CrossRef Medline

Zweig RM, Ross CA, Hedreen JC, Steele C, Cardillo JE, Whitehouse PJ, Folstein MF, Price DL (1989) Neuropathology of aminergic nuclei in Alzheimer's disease. Prog Clin Biol Res 317:353-365. Medline 